\title{
Warming of the Upper Equatorial Indian Ocean and Changes in the Heat Budget (1960-99)
}

\author{
GAËL AlORY \\ Laboratoire d'Etudes en Géophysique et Océanographie Spatiales, Toulouse, France, and CSIRO Marine and Atmospheric Research, \\ Hobart, Tasmania, Australia \\ GARY MEYERS \\ Integrated Marine Observing System, University of Tasmania, and CSIRO Marine and Atmospheric Research, Hobart, \\ Tasmania, Australia
}

(Manuscript received 16 November 2007, in final form 30 April 2008)

\begin{abstract}
In the equatorial Indian Ocean, sea surface has warmed by $0.5^{\circ}-1^{\circ} \mathrm{C}$ over the $1960-99$ period, while waters have cooled at thermocline depth and the net atmospheric heat flux has decreased. Among a set of twentieth-century climate simulations from 12 coupled models, the Centre National de Recherches Météorologiques Coupled Global Climate Model version 3 (CNRM-CM3) reproduces key observed features of these changes. It is used to investigate changes in the heat budget of the upper equatorial Indian Ocean and identify mechanisms responsible for the warming. By comparing twentieth-century and control simulations, significant shifts in the mean balance of the heat budget between the preindustrial and the 1960-99 periods can be identified. The main cause of the surface warming is a decrease in the upwellingrelated oceanic cooling. It occurs in the thermocline dome region because of a slowdown of the wind-driven Ekman pumping. The observed decrease in net heat flux is a negative feedback driven by evaporation, which is enhanced by the equatorial warming and associated strengthening of trade winds.
\end{abstract}

\section{Introduction}

Anthropogenic climate change is the main driver of the global oceanic warming observed during the past 50 years (Levitus et al. 2001; Barnett et al. 2005). Oceans play a key role in the climate system at this time scale as, because of their large heat capacity, they absorb most of the excess solar heating trapped by greenhouse gases (Levitus et al. 2005). The tropical Indian Ocean is a region where the surface warming signal has emerged at a steady pace during the past half century (Knutson et al. 2006). As sea surface temperature (SST) is an important variable for ocean-atmosphere coupling, the rising trend is likely to affect natural modes of variability like the Indian Ocean dipole (Saji et al. 1999) and its associated climatic impacts on the Asian monsoon (Krishnan et al. 2006) and Australian rainfall (Ashok et al. 2003). Atmospheric models have shown that the In-

Corresponding author address: Gaël Alory, LEGOS, 14 av. Edouard Belin, 31400 Toulouse, France.

E-mail: gael.alory@legos.obs-mip.fr dian Ocean warming trend is mostly responsible for droughts in the African Sahel (Giannini et al. 2003; Hoerling et al. 2006) and has a strong influence on the northern midlatitudes ( $\mathrm{Lu}$ et al. 2004; Hoerling et al. 2004), which can also result in droughts (Hoerling and Kumar 2003).

Observed temperature trends in the Indian Ocean present complex patterns that cannot be explained by surface heating alone. The heat storage has apparently increased more in the southern part than in the northern part of the Indian Ocean (Levitus et al. 2005), although this result may be biased by the sparse data coverage, particularly in the south (Harrison and Carson 2007). The strongest warming is found near the subtropical front and extends as deep as $800 \mathrm{~m}$; it is not directly linked to surface heating but rather due to a southward shift of the oceanic gyre circulation and associated thermal structure (Alory et al. 2007). Along the equator and in the southern tropics there is a shallow warming with a subsurface cooling below (Alory et al. 2007). Again, the surface warming here seems not to be directly linked to surface heating as heat flux prod- 
ucts do not show any increase in the last decade in the tropical Indian Ocean (Yu et al. 2007). But changes in the shallow meridional overturning circulation, which brings relatively cold subtropical waters to the tropics, have been reported and may play an important role (Lee 2004; Schoenefeldt and Schott 2006).

The goal of this paper is to test with a quantitative analysis the qualitative interpretation in the earlier paper by Alory et al. (2007), which concluded that ocean dynamics play a larger role in Indian Ocean warming than surface heat fluxes. To reach this goal, and more precisely to identify the mechanisms responsible for the equatorial SST warming, we make a long-term heat budget of the equatorial Indian Ocean surface layer. Data and models are presented in section 2. Climate model simulations are compared to available long-term observations of oceanic temperature and heat fluxes in the tropical Indian Ocean, to identify at least one model realistic enough to be used as a tool for the heat budget, in section 3. The heat budget analysis, including the long-term balance and changes in the 1960-99 period relative to the preindustrial period, is conducted in section 4 . Then a summary and discussion of our findings is presented in section 5 .

\section{Data and models}

\section{a. Data}

We use three different gridded sets of SST to identify long-term trends. The Extended Reconstructed SST (ERSST; Smith and Reynolds 2004) and Hadley Centre Sea Ice and SST dataset (HadISST; Rayner et al. 2003) are monthly reconstructions of SST based on combined satellite and in situ observations. To reconstruct the SST field, global spatial modes of SST variability are extracted from the satellite observations available since 1982 and are then fitted to observations including those from the presatellite era. The main difference between ERSST and HadISST is that in ERSST the fit is applied to in situ data (ship, drifting buoys and mooring), whereas in HadISST it is applied to both in situ and satellite data. Also, their spatial resolution is $2^{\circ}$ and $1^{\circ}$, respectively. The National Centers for Environmental Prediction (NCEP) SST is based on the Optimally Interpolated SST (Reynolds et al. 2002) from 1982, and the Global Sea Ice and SST (Rayner et al. 1996), for earlier periods. It has a $2^{\circ}$ spatial resolution and it is used to provide boundary conditions for the NCEP atmospheric reanalyses described later.

The Indian Ocean Thermal Archive (IOTA) is a compilation of historical temperature profiles that are quality controlled using both statistical and manual expert methods (Gronell and Wijffels 2008). The mean seasonal climatology is computed from a "loess" mapping method (Ridgway et al. 2002), which deals well with the varying data densities found in IOTA, and removed from observations. The long-term trend in the meridionally averaged equatorial ocean $\left(6^{\circ} \mathrm{N}-9^{\circ} \mathrm{S}\right)$ is then extracted from $5^{\circ} \times 5 \mathrm{yr}$ longitude-time bins by a linear fit weighted by the time-varying data density. The very low data density before 1960 makes IOTA hardly usable to compute trends before this time.

We use net heat fluxes and wind stress from the NCEP (Kistler et al. 2001) and 40-yr European Centre for Medium-Range Weather Forecasts (ECMWF) ReAnalysis (ERA-40; Uppala et al. 2005) atmospheric reanalyses. These reanalyses are outputs from global atmospheric models that use SST as a boundary condition and assimilate available atmospheric observations. NCEP and ERA-40 reanalyses have, respectively, a spatial resolution of $2^{\circ}$ and $2.5^{\circ}$, and start in 1948 and 1957, which allows their comparison from 1960 on.

\section{b. Models}

We selected 12 climate models from the World Climate Research Programme's (WCRP's) Coupled Model Intercomparison Project phase 3 (CMIP3) multimodel dataset. The selection is based on the availability of surface/subsurface temperature and heat fluxes outputs, and also excludes some outdated model versions. Models resolution is given in Table 1; more details can be found in given references or online (http:// www-pcmdi.llnl.gov/ipcc/model_documentation/ipcc_ model_documentation.php). The set of simulations compared to long-term observations is the so-called Climate of the Twentieth-Century Experiment (20C3M), which includes changes in radiative forcing including greenhouse gases, aerosols, and volcanic and solar forcing. The 20C3M experiments end in 1999 for most models, which prevents comparison to observations in more recent years.

For the Centre National de Recherches Météorologiques Coupled Global Climate Model version 3 (CNRM-CM3), the 500-yr-long Preindustrial Control Experiment (PICNTRL) that does not include changes in radiative forcing is used to estimate the range of natural coupled variability and compared to the $20 \mathrm{C} 3 \mathrm{M}$ run of the same model. To reduce interpolation errors, all heat budget terms are computed in CNRM-CM3 from the original outputs on the irregular grid of the Océan Parallélisé (OPA) oceanic component (Madec et al. 1998), rather than from the interpolated outputs provided to the WCRP CMIP3 database. The vertical grid resolution is $10 \mathrm{~m}$ from 5 to $105 \mathrm{~m}$ and $25 \mathrm{~m}$ near $200 \mathrm{~m}$. The mixed layer depth is defined in the model as 
TABLE 1. Brief description of the models used in this study. The grid resolution is given at the equator $\left({ }^{\circ}\right.$ lat $\times{ }^{\circ}$ lon $)$.

\begin{tabular}{|c|c|c|c|}
\hline \multirow[b]{2}{*}{ Model } & \multicolumn{2}{|c|}{ Resolution } & \multirow[b]{2}{*}{ Reference } \\
\hline & Atmosphere & Ocean & \\
\hline BCCR-BCM2.0 & $2.8 \times 2.8$ & $1 \times 1$ & Furevik et al. (2003) \\
\hline $\begin{array}{l}\text { Canadian Centre for Climate Modelling and Analysis (CCCma) Coupled } \\
\text { General Circulation Model, version } 3.1 \text { (CGCM3.1-T63) }\end{array}$ & $2.8 \times 2.8$ & $0.93 \times 1.4$ & Flato et al. (2000) \\
\hline CNRM-CM3 & $2.8 \times 2.8$ & $0.5 \times 2$ & Salas-Melia et al. (2005) \\
\hline $\begin{array}{l}\text { Commonwealth Scientific and Industrial Research Organisation Mark } \\
\text { version 3.0 (CSIRO MK3.0) }\end{array}$ & $1.9 \times 1.9$ & $0.9 \times 1.9$ & Gordon et al. (2002) \\
\hline CSIRO MK3.5 & $1.9 \times 1.9$ & $0.9 \times 1.9$ & Gordon et al. (2002) \\
\hline GFDL CM2.0 & $2 \times 2.5$ & $0.33 \times 1$ & Delworth et al. (2006) \\
\hline GFDL CM2.1 & $2 \times 2.5$ & $0.33 \times 1$ & Delworth et al. (2006) \\
\hline IAP FGOALS & $2.8 \times 2.8$ & $1 \times 1$ & Yu et al. (2004) \\
\hline L'Institut Pierre-Simon Laplace Coupled Model, version 4 (IPSL CM4) & $2.5 \times 3.75$ & $0.5 \times 2$ & Marti et al. (2005) \\
\hline $\begin{array}{l}\text { Model for Interdisciplinary Research on Climate 3.2, high-resolution } \\
\text { version [MIROC3.2(hires)] }\end{array}$ & $1.12 \times 1.12$ & $0.56 \times 1.12$ & Hasumi and Emori (2004) \\
\hline MRI CGCM2.3.2 & $2.8 \times 2.8$ & $0.5 \times 2.5$ & Yukimoto and Noda (2002) \\
\hline $\begin{array}{l}\text { Met Office Third Hadley Centre Coupled Ocean-Atmosphere GCM } \\
\text { (UKMO HadCM3) }\end{array}$ & $2.5 \times 3.75$ & $1.25 \times 1.25$ & Gordon et al. (2000) \\
\hline
\end{tabular}

the depth where in situ density is $0.01 \mathrm{~kg} \mathrm{~m}^{-3}$ larger than the surface density. Only monthly averaged model outputs were available for this study.

\section{Model validation}

The focus of this multimodel validation is on the equatorial Indian Ocean. The objective is to identify at least one model that reproduces the main features of observed long-term trends so that it can be used as a tool to estimate changes in the regional heat budget, rather than trying to investigate causes for intermodel differences.

\section{a. Sea surface temperature}

Observed and simulated long-term trends in SST are compared in Fig. 1. Observations show a general SST warming in the tropical Indian Ocean. This warming is particularly large along the equator east of $60^{\circ} \mathrm{E}$, exceeding $1^{\circ} \mathrm{C}$ over $40 \mathrm{yr}$ in the HadISST and NCEP datasets. It has been suggested that such an enhanced equatorial warming relative to the subtropics is an important tropical SST fingerprint to global warming (Liu et al. 2005). All models reproduce an overall warming. However, they show large differences in their warming pattern and some even show local cooling areas. The few models with a distinct equatorial tongue of warming are the Bjerknes Centre for Climate Research Bergen Climate Model version 2.0 (BCCR-BCM2.0), Institute of Atmospheric Physics Flexible Global Ocean-Atmosphere-Land System (IAP FGOALS), and CNRM-CM3.

SST time series spatially averaged in the $9^{\circ} \mathrm{S}-6^{\circ} \mathrm{N}$ equatorial band for the observations and the CNRMCM3 model are shown in Fig. 2. The mean modeled SST is about $2^{\circ} \mathrm{C}$ colder than observed. This is a known bias in the model; however, the simulated equatorial SST distribution correctly reproduces an equatorial warm pool extending over the western Pacific and eastern Indian Oceans. Also, this cold bias does not prevent this model from being one of the more realistic at simulating the mechanisms of interannual variability of the tropical Indian Ocean (Saji et al. 2006) and hopefully those operating at longer time scales. The interannual variability in the coupled model has, as expected, an amplitude close to observations. The long-term warming is estimated as a linear trend over $40 \mathrm{yr}$. It ranges from $0.49^{\circ}$ to $0.70^{\circ} \mathrm{C}$ for observations, which is $95 \%$ significant for HadISST and NCEP SST. It is slightly larger $\left(0.76^{\circ} \mathrm{C}\right)$ for the model, where it is also $95 \%$ significant. Also, whether the temperature is averaged in the upper 50-m layer or in the mixed layer, it has the same interannual signal and long-term trend as SST (Fig. 2), which means the heat budget could be done in either of these layers to investigate the cause of SST warming.

\section{b. Subsurface temperature}

Long-term trends in subsurface temperature can reflect changes in subsurface oceanic processes. They are compared for observations and models in the equatorial Indian Ocean in Fig. 3. Observations show a cooling between 50 and $200 \mathrm{~m}$, reaching a maximum of $1^{\circ} \mathrm{C}$ over $40 \mathrm{yr}$. It is centered on the $20^{\circ} \mathrm{C}$ isotherm, which indicates the thermocline depth. This cooling corresponds to a shoaling of the thermocline and, associated 


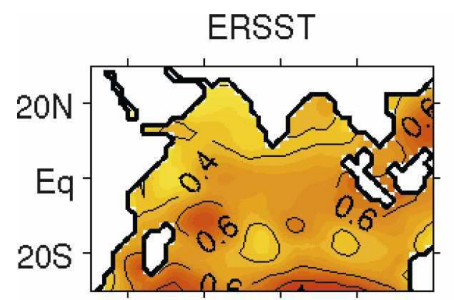

BCCR-BCM2.0

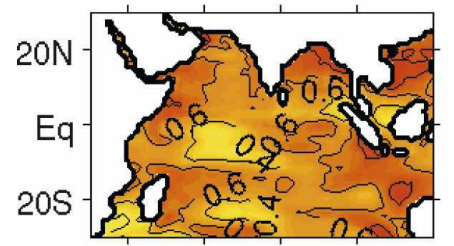

CSIRO-MK3.5

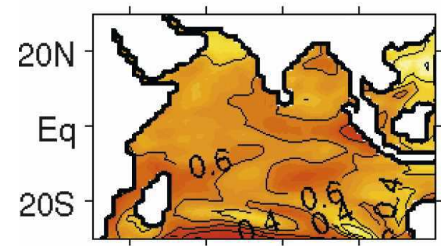

IPSL-CM4

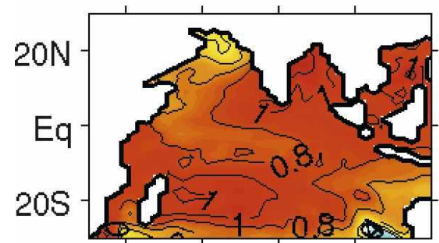

$40 \mathrm{E} 60 \mathrm{E} \quad 80 \mathrm{E} 100 \mathrm{E}$
HADISST

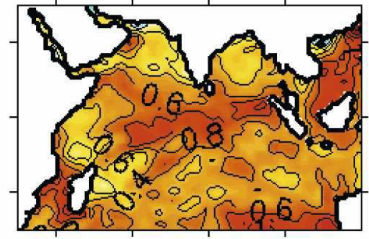

CGCM3.1-T63

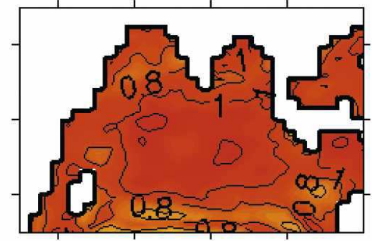

GFDL-CM2.0

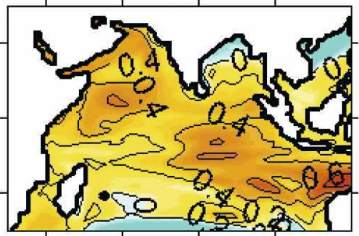

MIROC3.2.HI

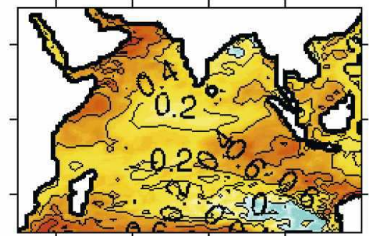

40E 60E 80E 100E
NCEP

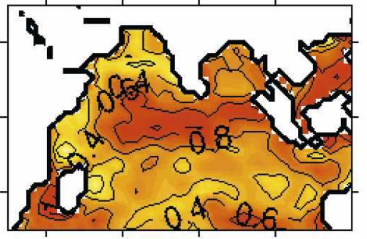

CNRM-CM3

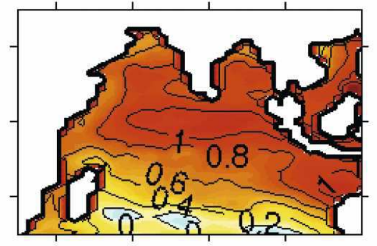

GFDL-CM2. 1

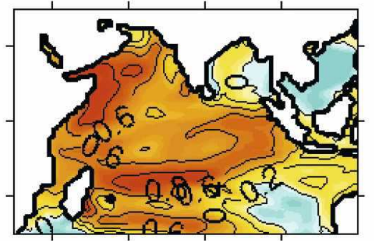

MRI-GGCM2.3.2

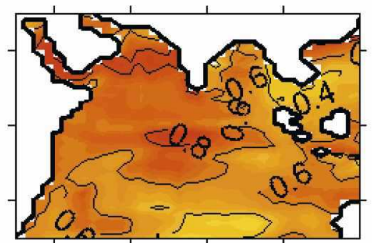

$40 \mathrm{E} 60 \mathrm{E} 80 \mathrm{E} 100 \mathrm{E}$

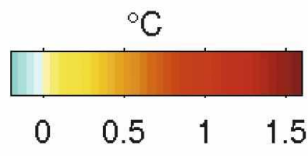

CSIRO-MK3

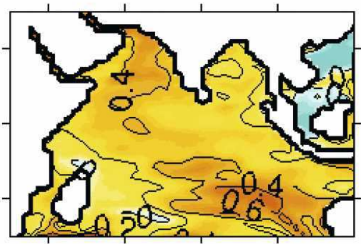

IAP-FGOALS

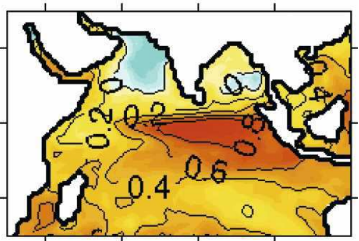

UKMO-HADCM3

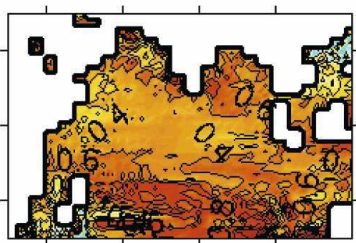

$40 \mathrm{E} 60 \mathrm{E} 80 \mathrm{E} 100 \mathrm{E}$

FIG. 1. Linear trend of SST $\left({ }^{\circ} \mathrm{C}\right)$ for the $1960-99$ period from 3 sets of observations and 12 climate models.

with the surface warming, results in an increase of the vertical stratification. The subsurface cooling is found in only half of the models: BCCR-BCM2.0, Geophysical Fluid Dynamics Laboratory Climate Model version 2.0 (GFDL CM2.0), GFDL CM2.1, IAP FGOALS, Meteorological Research Institute Coupled General Circulation Model version 2.3.3 (MRI CGCM2.3.3), and CNRM-CM3.

The subsurface temperature trend is then spatially averaged in the equatorial Indian Ocean for the CNRM-CM3 model and more quantitatively compared to the observed trend (Fig. 4). The simulated subsurface cooling is as large as but shallower than observed, which is consistent with the location of the $20^{\circ} \mathrm{C}$ isotherm, also shallower in the model than observed (Fig. 3 ). The shallow location of isotherms in the model is itself consistent with the cold SST bias already noted. The upper-layer warming is larger in the model than observed, which, combined with the shallower cooling, makes for an upper heat content increase almost similar to observed.

\section{c. Heat flux}

Surface heat fluxes are with SST the most important variables for thermodynamic coupling between ocean and atmosphere at all time scales. The long-term mean and trend in net surface heat fluxes are compared for atmospheric reanalyses and models in Fig. 5. The mean downward net heat flux is positive over the equatorial Indian Ocean, and reanalyses and models roughly agree on a value around $20 \mathrm{Wm}^{-2}$. However, there are large differences among trend values. Both reanalyses show a decrease over the equatorial Indian Ocean from 1960 to 1999 , although with a very different magnitude. Models have relatively small trends in the net heat flux and only a couple of them, namely BCCR-BCM2.0 and CNRM-CM3, show a pronounced decrease in net heat flux (Fig. 5). The most consistent trend among heat flux 


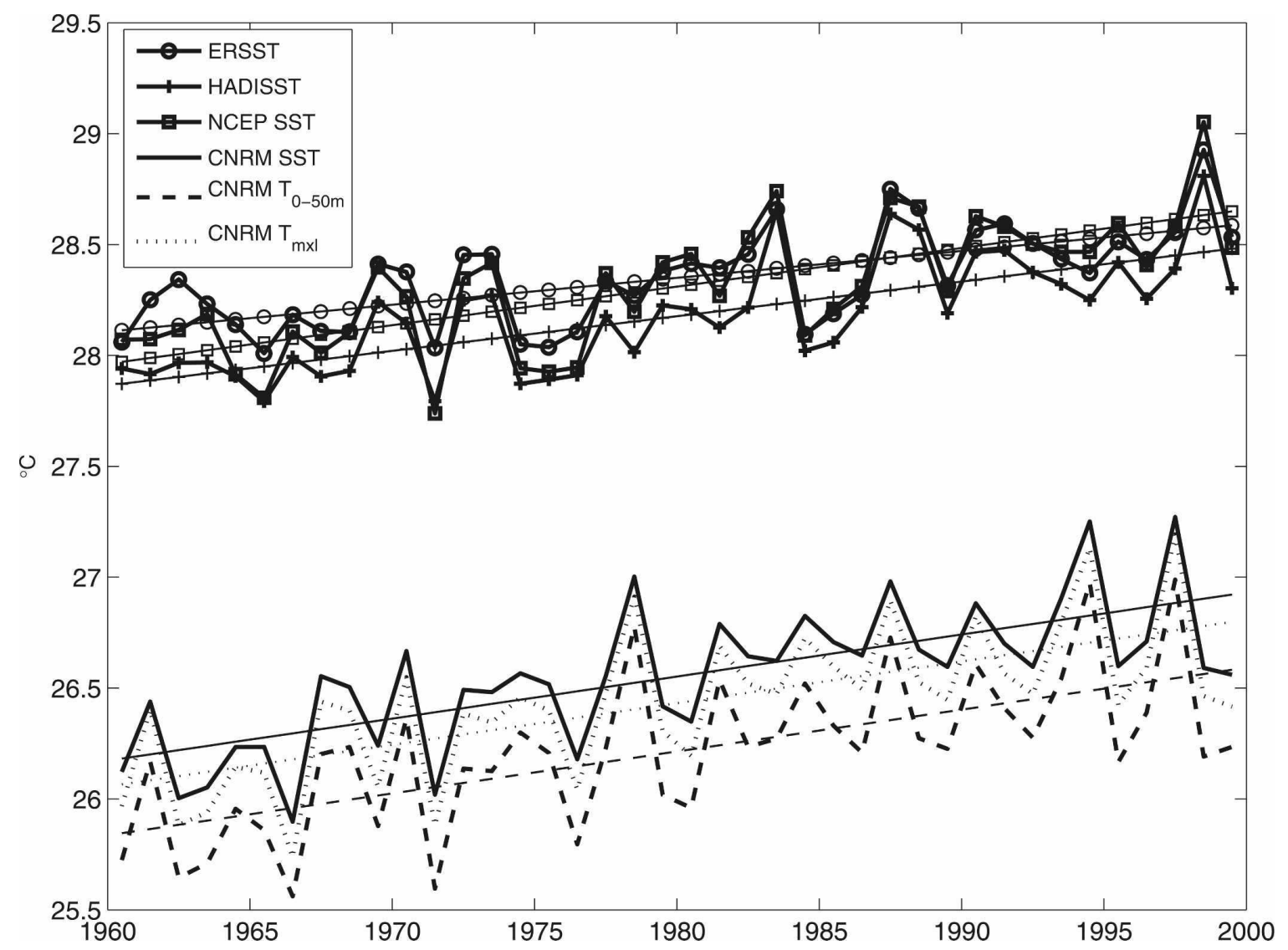

FIG. 2. SST from 3 sets of observations and SST and vertically averaged temperature in the mixed layer and in the 0-50-m layer from CNRM-CM3. All variables are horizontally averaged in the equatorial Indian Ocean $\left(9^{\circ} \mathrm{S}-6^{\circ} \mathrm{N}\right)$. Thin lines show the long-term linear trend.

components in NCEP and ERA-40 reanalyses is an increase in the latent heat flux, which is also found in all but one model (not shown).

\section{d. Wind stress}

Available data suggest that SST increased although heat fluxes decreased over 1960-99, therefore climate dynamics may play a larger role than thermodynamics for the sea surface warming. Wind stress and ocean dynamics are closely related, particularly near the surface. As CNRM-CM3 is one of the only models able to reproduce both SST and heat flux trends, it is important to check how it simulates winds. The seasonal variations and long-term trends of wind stress in CNRM$\mathrm{CM} 3$ are shown, and the later compared to the trends found in atmospheric reanalyses, in Fig. 6.

The monsoon cycle, which peaks in January and July, is a major feature of the Indian Ocean (Schott and McCreary 2001). In January (Fig. 6a), northeast monsoon winds are found north of the equator and weak westerlies are found between the equator and $10^{\circ} \mathrm{S}$. In
July (Fig. 6b), this pattern is reversed, with particularly strong southwest monsoon winds in a narrow band of the Arabian Sea forming the Findlater (1969) jet. The southwest monsoon pattern dominates the annual mean (Fig. 6c). South of $10^{\circ} \mathrm{S}$, the tropical Indian Ocean is characterized by a trade wind circulation, stronger in July than January. These simulated seasonal wind variations are consistent with observations (Schott and McCreary 2001).

The trends in wind stress and wind speed over the 1960-99 period simulated by CNRM-CM3 are compared to those found in NCEP and ERA-40 reanalyses (Figs. 6d-f). While the climatological mean is similar for the three wind fields (not shown), there are large differences between their respective trends. In the model, there is a strengthening of trade winds south of the equator, a westward trend along the equator, and relatively small trends in the Arabian Sea and Bay of Bengal. The strengthening in trade winds is also found south of $10^{\circ} \mathrm{S}$ in ERA- 40 but only in a few patches near Madagascar and Australia in NCEP, as a strong east- 

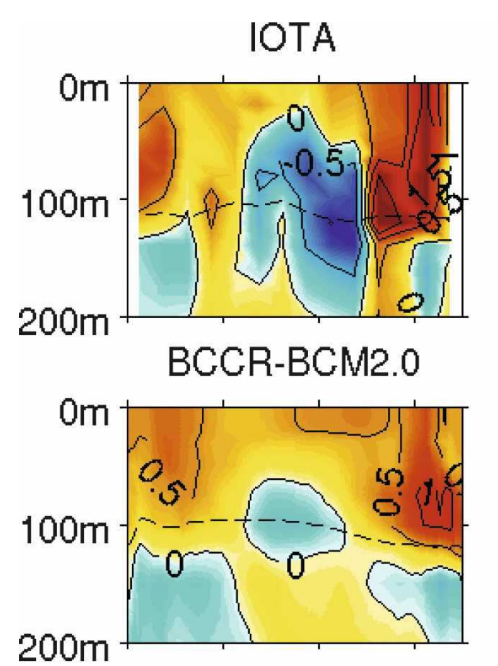

CSIRO-MK3.5

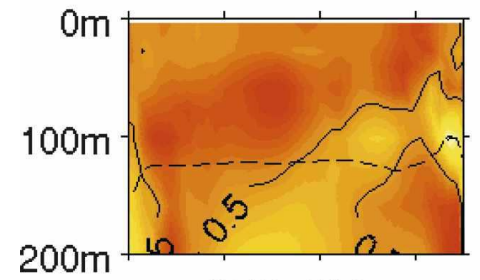

IPSL-CM4

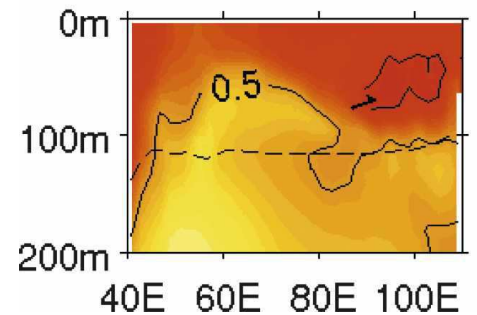

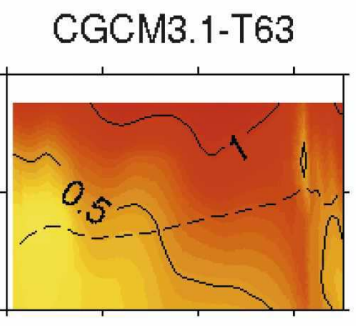

GFDL-CM2.0

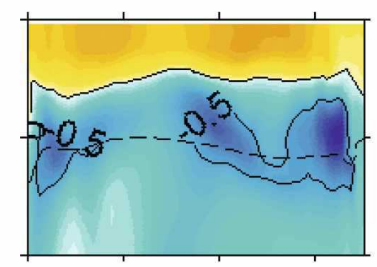

MIROC3.2.HI

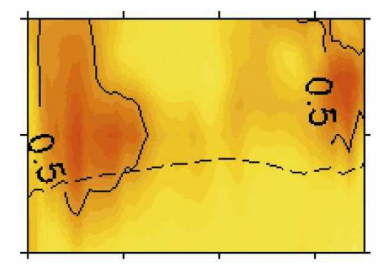

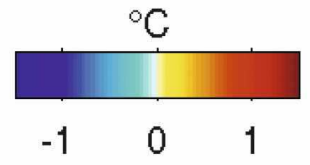

CNRM-CM3

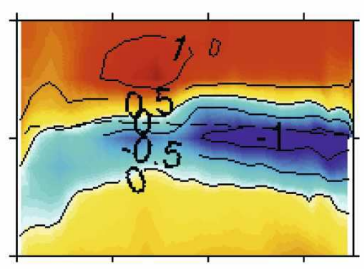

GFDL-CM2.1

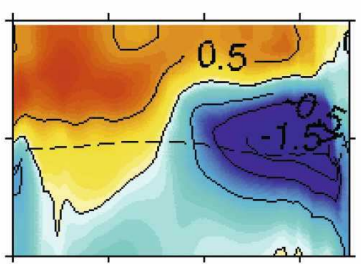

MRI-CGCM2.3.2

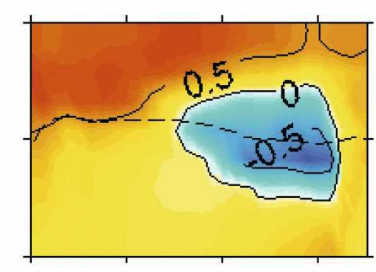

$40 \mathrm{E} 60 \mathrm{E} \quad 80 \mathrm{E} 100 \mathrm{E}$

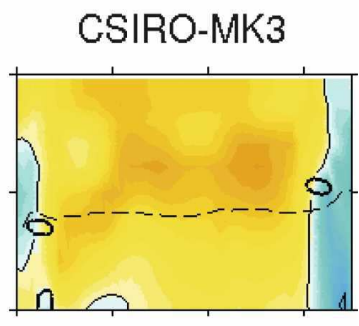

IAP-FGOALS

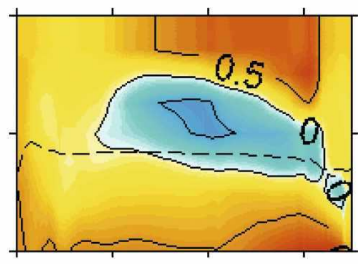

UKMO-HADCM3

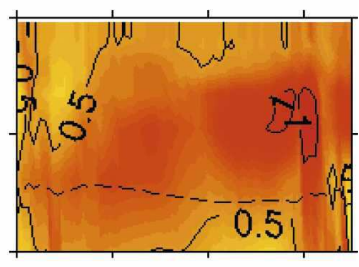

$40 \mathrm{E} \quad 60 \mathrm{E} \quad 80 \mathrm{E} 100 \mathrm{E}$

FIG. 3. Lon-depth slice of the linear trend (colors) of subsurface temperature for the 1960-99 period averaged in the equatorial band $\left(9^{\circ} \mathrm{S}-6^{\circ} \mathrm{N}\right)$ from IOTA dataset and 12 climate models. The dashed line is the mean position of the $20^{\circ} \mathrm{C}$ isotherm.

ward trend dominates the southern tropics in this product. Along the equator, there is a strong eastward trend in ERA-40, while the trend oscillates from eastward to slightly westward in NCEP. Only in the Arabian Sea and Bay of Bengal do ERA-40 and NCEP agree on a strong northeasterly wind trend. Given the differences between NCEP and ERA-40, it is difficult to validate the model winds. It has been shown that wind reanalyses include spurious trends due to changes in the observing systems (Alory et al. 2005). In the equatorial band, because of spurious trends in wind observations, sea level pressure gradient is often used as an alias to study long-term wind changes (Clarke and Lebedev 1996). Using this approach, Vecchi et al. (2006) showed that equatorial Pacific trade winds weakened since the mid-nineteenth century because of a greenhouse-forced slowdown of the Indo-Pacific Walker circulation. The equatorial westward wind trend simulated by CNRMCM3 is the expected signature of this slowdown in the Indian Ocean (Vecchi and Soden 2007).

\section{e. Oceanic circulation}

The CNRM-CM3 model is further validated by checking how it simulates large-scale oceanic circulation. The tropical Indian Ocean is closed by a northern boundary, so its water exchanges with the other basins can be quickly diagnosed by looking at the top to bottom transports in the Indonesian Throughflow (ITF) and the Mozambique Channel, where direct observations are available, and whose difference gives the transport between Madagascar and Australia because of mass conservation. The mean simulated inflow from the ITF and outflow to the Mozambique Channel are, respectively, 9.3 and $15.5 \mathrm{~Sv}\left(1 \mathrm{~Sv} \equiv 10^{6} \mathrm{~m}^{3} \mathrm{~s}^{-1}\right)$, close 


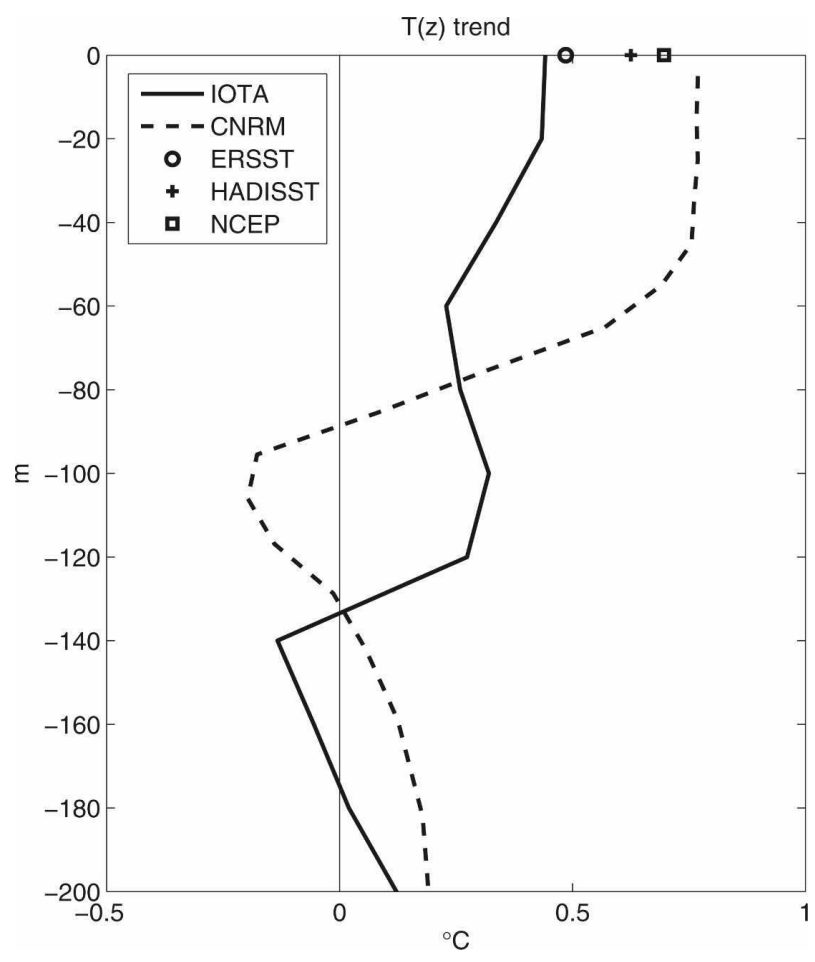

FIG. 4. Vertical profile of the 1960-99 temperature trend averaged in the equatorial Indian Ocean $\left(9^{\circ} \mathrm{S}-6^{\circ} \mathrm{N}\right)$ from IOTA and CNRM-CM3, and SST trend from 3 sets of observations.

to the observed values of $10 \mathrm{~Sv}$ (Gordon 2005) and 14 Sv (Ridderinkhof and de Ruijter 2003).

Shallow meridional cells are a major feature of the tropical oceans that connect them to the subtropics. While meridional transport streamfunctions are often difficult to interpret as they only provide a zonally integrated picture and integrate different physical processes, they are a useful tool to identify meridional cells. The seasonal variations, climatological mean and long-term trend of the CNRM-CM3 meridional transport streamfunction are shown in Fig. 7 north of the ITF.

The streamfunction has large seasonal variations. In January (Fig. 7a), the winds (Fig. 6a) induce a northward Ekman flow both sides of the equator in the upper $100 \mathrm{~m}$, which drives a clockwise overturning circulation. In July (Fig. 7b), as the wind pattern is reversed (Fig. $6 \mathrm{~b})$, the overturning circulation is counterclockwise, with two meridional cells. North of $10^{\circ} \mathrm{N}$, waters of subtropical origins moves upward and feed the Northern Hemisphere upwelling areas off Somalia and Oman before moving southward, this is the cross-equatorial cell (Miyama et al. 2003). South of the equator, a second cell feeds open-ocean upwelling in the thermocline dome area $\left(5^{\circ}-10^{\circ} \mathrm{S}\right)$ before joining the southward flow, this is the southern cell (Schott et al. 2002). Also, in the upper $50 \mathrm{~m}$ near the equator, there is an equatorial roll that reverses seasonally, driven by the opposite Ekman transport and equatorial meridional wind, and that has been directly observed (Schott et al. 2002). Overall, the seasonal variations of the meridional transport streamfunction in CNRM-CM3 are very consistent with those found in the GFDL model (Lee and Marotzke 1998).

On annual mean, the only hint of a cross-equatorial cell in the meridional transport streamfunction is found near 100-m depth with a very restricted extension in the Northern Hemisphere, while a southern cell is still present (Fig. 7c). The southern cell is therefore the dominant feature of the meridional circulation in CNRM-CM3. A similar annual mean streamfunction is found in a forced version of the Modular Ocean Model version 2 (MOM2; Hu et al. 2005), while the southwest monsoon pattern dominates the annual mean in the coupled Japan Agency for Marine-Earth Science and Technology (JAMSTEC) model (Miyama et al. 2003). More generally, the northward extension of the annual mean cross-equatorial cell in the WCRP CMIP3 database is strongly model dependent (not shown).

The long-term trend of the streamfunction (Fig. 7d) mostly shows an anticlockwise cell south of the equator and a smaller clockwise cell north of the equator in the upper $100 \mathrm{~m}$. This corresponds to an equatorial upwelling anomaly and a downwelling anomaly in the $5^{\circ}$ $10^{\circ} \mathrm{S}$ latitude band.

\section{Heat budget}

Based on the above multimodel comparison, CNRMCM3 is one of the very few models to reproduce observed trends in SST, subsurface temperature, and heat flux on the 1960-99 period, in particular the coinciding increase in SST and decrease in heat flux. Moreover, the climatological oceanic circulation simulated by this model is consistent with our current knowledge in the Indian Ocean, while long-term trends of this circulation are not available from observations. The CNRM-CM3 model may therefore provide a possible explanation of processes at work in the real ocean and responsible for the observed SST trend. It is used here as a tool to investigate changes in the heat budget responsible for the SST warming.

\section{a. Heat budget formulation}

The $9^{\circ} \mathrm{S}-6^{\circ} \mathrm{N}$ equatorial band, where the SST warming is rather homogeneous (Fig. 1), is the geographical domain chosen to assess the heat budget. Our hypothesis is that heat transports through large sections are responsible for the warming. As heat transport can be highly variable at one grid point, the analysis in a large box helps increase the signal-to-noise ratio. The 


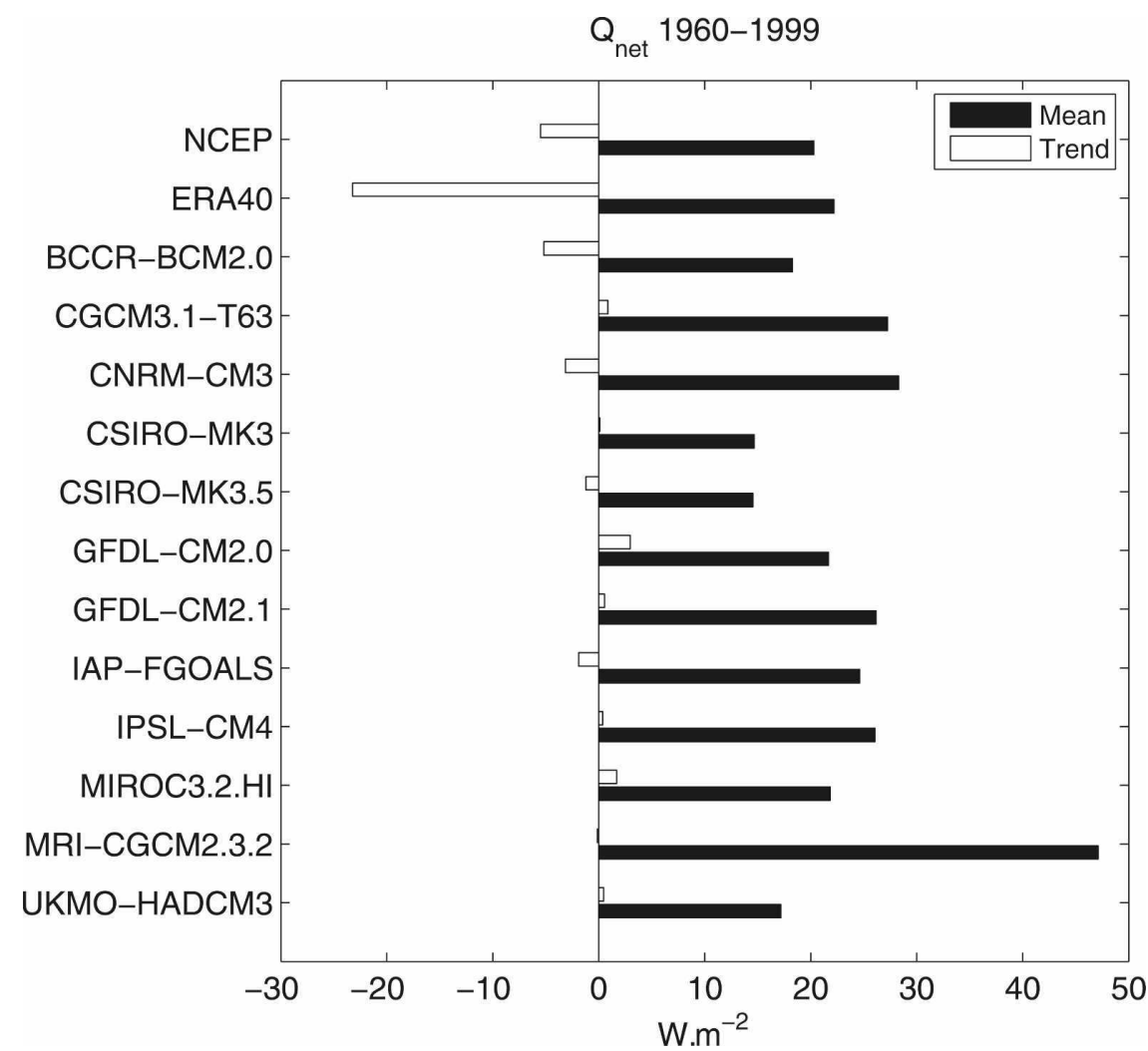

FIG. 5. Mean and linear trend of net downward heat flux for the 1960-99 period averaged in the equatorial Indian Ocean $\left(9^{\circ} \mathrm{S}-6^{\circ} \mathrm{N}\right)$ from NCEP and ERA-40 atmospheric reanalyses and 12 climate models.

$9^{\circ} \mathrm{S}-6^{\circ} \mathrm{N}$ box has continental boundaries to the west and east so there is no zonal advection term. As the $0-50-\mathrm{m}$ layer temperature and SST have a similar warming trend (Fig. 2), a fixed bottom at $50 \mathrm{~m}$ is chosen for the heat budget to avoid entrainment terms. Reducing the number of terms eases interpretation but also reduces potential error sources in the computation. The heat budget is formulated as

$$
\frac{\partial T_{\mathrm{box}}}{\partial t}=\frac{1}{\nu_{\mathrm{box}}}\left[\iint_{S_{0}} \frac{Q_{0}-Q_{h}}{\rho C_{p}} d x d y+\iint_{S_{L}} V\left(T-T_{\mathrm{box}}\right) d x d z+\iint_{S_{h}} W\left(T-T_{\mathrm{box}}\right) d x d y+R\right],
$$

where $T$ is temperature; $T_{\text {box }}$ is the temperature spatially averaged in the domain; $t$ is time; $\nu_{\text {box }}, S_{0}, S_{L}$, and $S_{h}$ are, respectively, the volume, surface, lateral, and bottom boundaries of the domain; $Q_{0}$ and $Q_{h}$ are, respectively, the net heat flux at the surface and penetrating deeper than $h=50 \mathrm{~m} ; \rho$ and $C_{p}$ are the density and heat capacity of seawater; $V$ and $W$ are the meridional and vertical current; and $R$ is a residual term. The use of temperature anomalies relative to the domain temperature is recommended to take into account external advection processes only in the heat budget (Lee et al. 2004). In the heat flux term, $Q_{h}$ is about $5 \%$ of the shortwave heat flux with the ocean transparency as- sumed in the model. Advection through the lateral boundaries includes heat exchanges with the Arabian Sea, Bay of Bengal, and southern Indian Ocean. Vertical advection is expected to reflect upwelling processes occurring in the Indian Ocean. The residual term includes diffusion and subgrid-scale mixing processes but also potential errors in the heat terms computation.

\section{b. Heat budget balance}

In this section we evaluate the temperature change from one year to the next simulated by the CNRMCM3 twentieth-century run and assess which mechanisms represented by the terms in Eq. (1) control the 
(a) CNRM-CM3 $\tau$ January

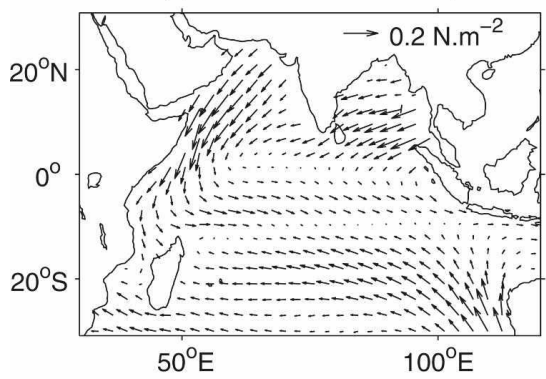

(c) CNRM-CM3 $\tau$ Mean

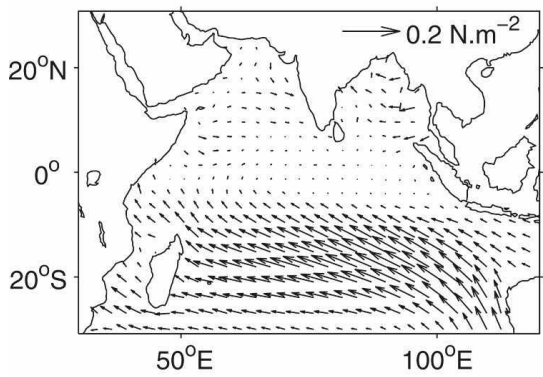

(e) NCEP $\tau$ Trend

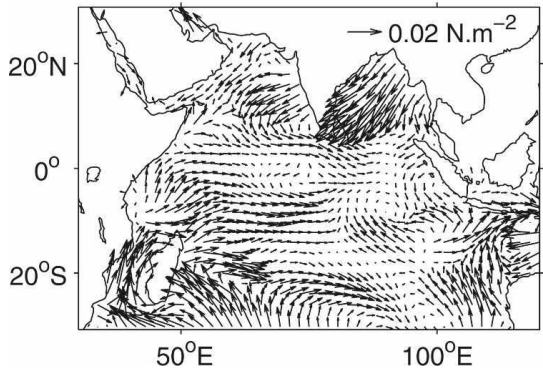

(b) CNRM-CM3 $\tau$ July

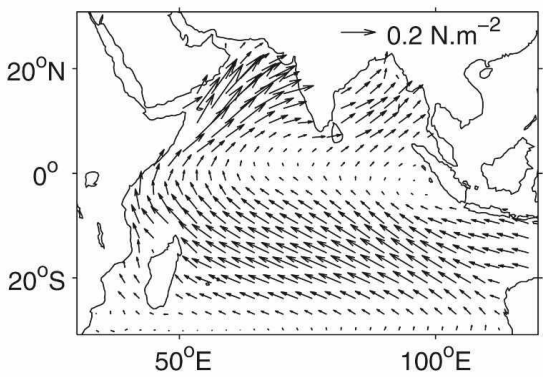

(d) CNRM-CM3 $\tau$ Trend

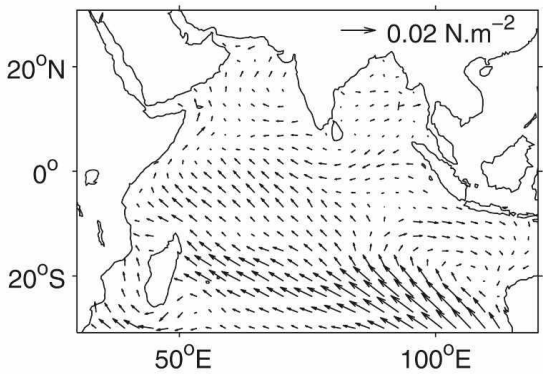

(f) ERA40 $\tau$ Trend

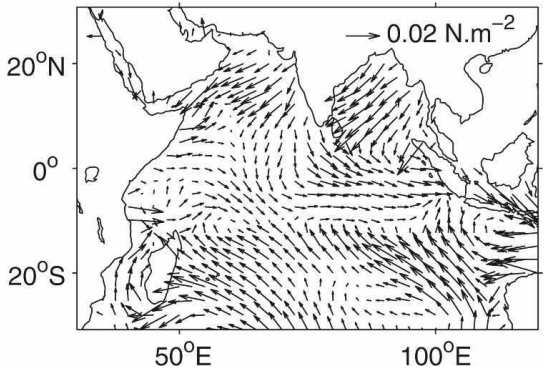

FIG. 6. (a) January mean, (b) July mean, (c) annual mean, and (d) long-term trend of wind stress in the CNRM-CM3 model over the 1960-99 period. (e) Long-term trend of wind stress in NCEP and (f) ERA-40 reanalyses over the same period.

changes. The annual values of heat budget terms are shown in Fig. 8. They are computed from monthly model outputs following Eq. (A6), which makes them representative of interannual variability (see appendix A). The mean value of each heat budget term over the 1960-99 period is reported in Table 2. On average, heat fluxes contribute to warming $\left(2.5^{\circ} \mathrm{C} \mathrm{yr}^{-1}\right)$ while vertical

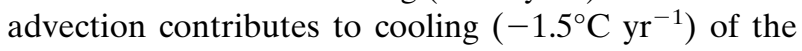
equatorial Indian Ocean. Meridional advection has a rather small contribution. The decreasing trend in the heat flux term discussed previously is the largest trend of all heat terms.

The annual temperature change simulated by the model ( $d T$ in Fig. 8) and the annual change reconstituted from the sum of the atmospheric and advective heat terms $[d T(Q+V T+W T)$ in Fig. 8] are highly correlated $(r=0.95)$ with a similar amplitude $\{\sigma(d T) /$ $\sigma[d T(Q+V T+W T)]=1.07\}$. This means this heat budget formulation explicitly resolves most of the interannual variability of SST, and diffusion-eddy processes can be neglected at this time scale.

The difference between the simulated and reconstituted temperature change (Fig. 8) is an estimate of the annual strength of the diffusion-eddy processes. This

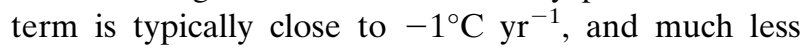
variable at the interannual time scale than surface fluxes or upwelling. The vertical subgrid-scale processes are parameterized in the CNRM-CM3 model as $K_{z} \partial T / \partial z$, where $K_{z}$ is a vertical eddy viscosity and diffusivity coefficient and $\partial T / \partial z$ is the vertical temperature gradient. Because of large submonthly variations in $K_{z}$ and $\partial T / \partial z$ near the base of the mixed layer, this term cannot be estimated from monthly averaged data. Since only monthly data is available for this study at this time, there is no choice but to compute diffusion as a residual term. A previous model study where the surface flux, 
(a) $\psi$ January

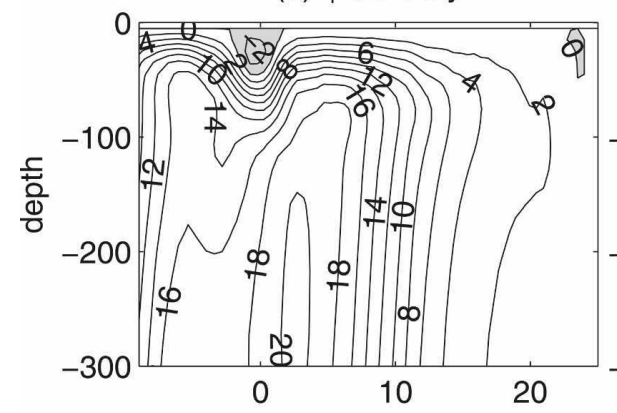

(c) $\psi$ Mean (b) $\psi$ July

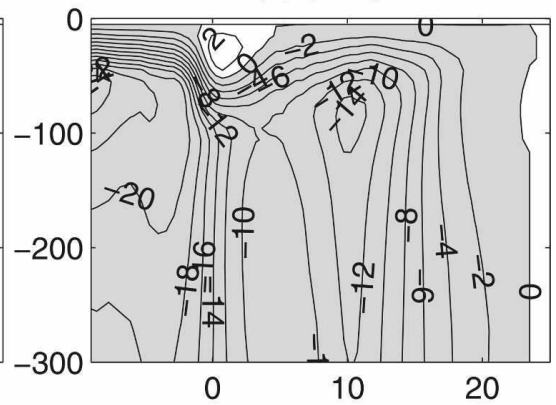

(d) $\psi$ Trend
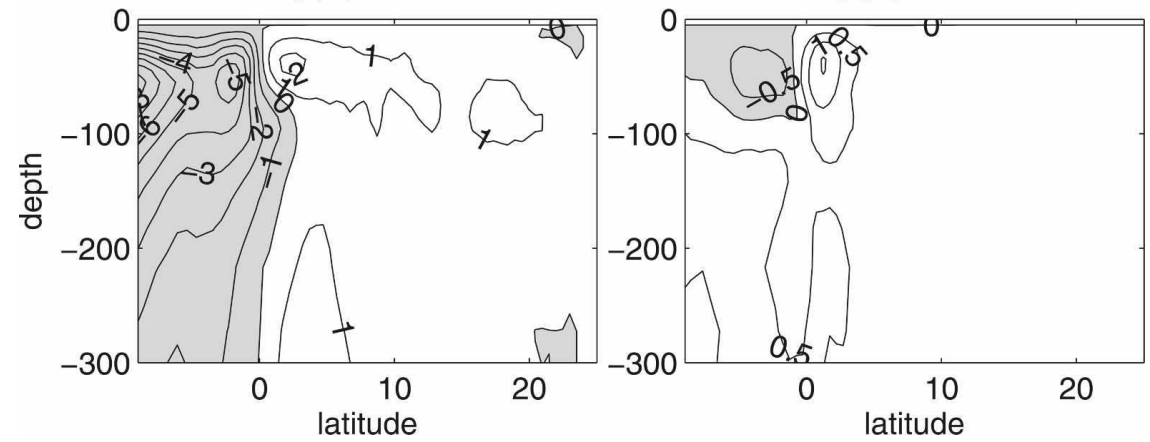

FIG. 7. (a) January mean, (b) July mean, (c) annual mean, and (d) long-term trend of the meridional transport streamfunction (Sv) in CNRM-CM3 over the 1960-99 period. White (gray) areas indicate a clockwise (counterclockwise) circulation.

advection and vertical diffusion terms were all explicitly computed at high frequency shows that the sum of these heat terms allows the closure of the multidecadal heat budget of the equatorial upper ocean (Cai and Whetton 2001).

\section{c. Changes in the heat budget relative to the preindustrial period}

As demonstrated in appendix $\mathrm{B}$, the main drivers for the long-term trend in temperature are the long-term means of the different heat terms. To investigate changes in the heat budget linked to the ongoing climate change, the mean balance of the heat budget over 1960-99 estimated from the twentieth-century simulation (Fig. 8) can be compared to a similar long-term heat budget estimated from the preindustrial control simulation also available for the CNRM-CM3 model. The relatively weak variability of the residual term representing submonthly diffusive/eddy processes noted in Fig. 8 is consistent with assuming that this term is not very different between the two periods. The assumption can be tested in the future using higher-frequency model output.

A running 40-yr heat budget is thus computed from the 500-yr-long control simulation, to represent the range of natural variability with statistical significance.
The probability density function (PDF) for a 40-yr temperature trend (from a linear fit), 40-yr temperature change (from a simple year-to-year difference), and 40$\mathrm{yr}$ mean of each heat term in the preindustrial state are compared in Fig. 9 to the same terms corresponding to the 1960-99 period. The heat budget tendencies for the preindustrial and 1960-99 simulations and the percent of significance $(p)$ of the changes due to radiative forcing, deduced by comparing these simulations, are reported in Table 2. Most of the PDFs look like normal distributions, which suggests the 500-yr control simulation is long enough to provide a significant statistical analysis. While the 1960-99 temperature trend is far outside the range of natural variability (Fig. 9a; $p=$ $100 \%$ ), the temperature change on this same period is less significant (Fig. 9b; $p=82 \%$ ) as it underestimates the former because of interannual variability (see appendix B). The effect of interannual variability could be reduced by averaging several ensemble simulations, which were unfortunately not available for the CNRMCM3 model. However, if significant changes in the heat budget are found in this critical underestimation case, their significance is potentially reinforced in other cases.

There are indeed significant changes in the heat terms between the preindustrial state and the 1960-99 


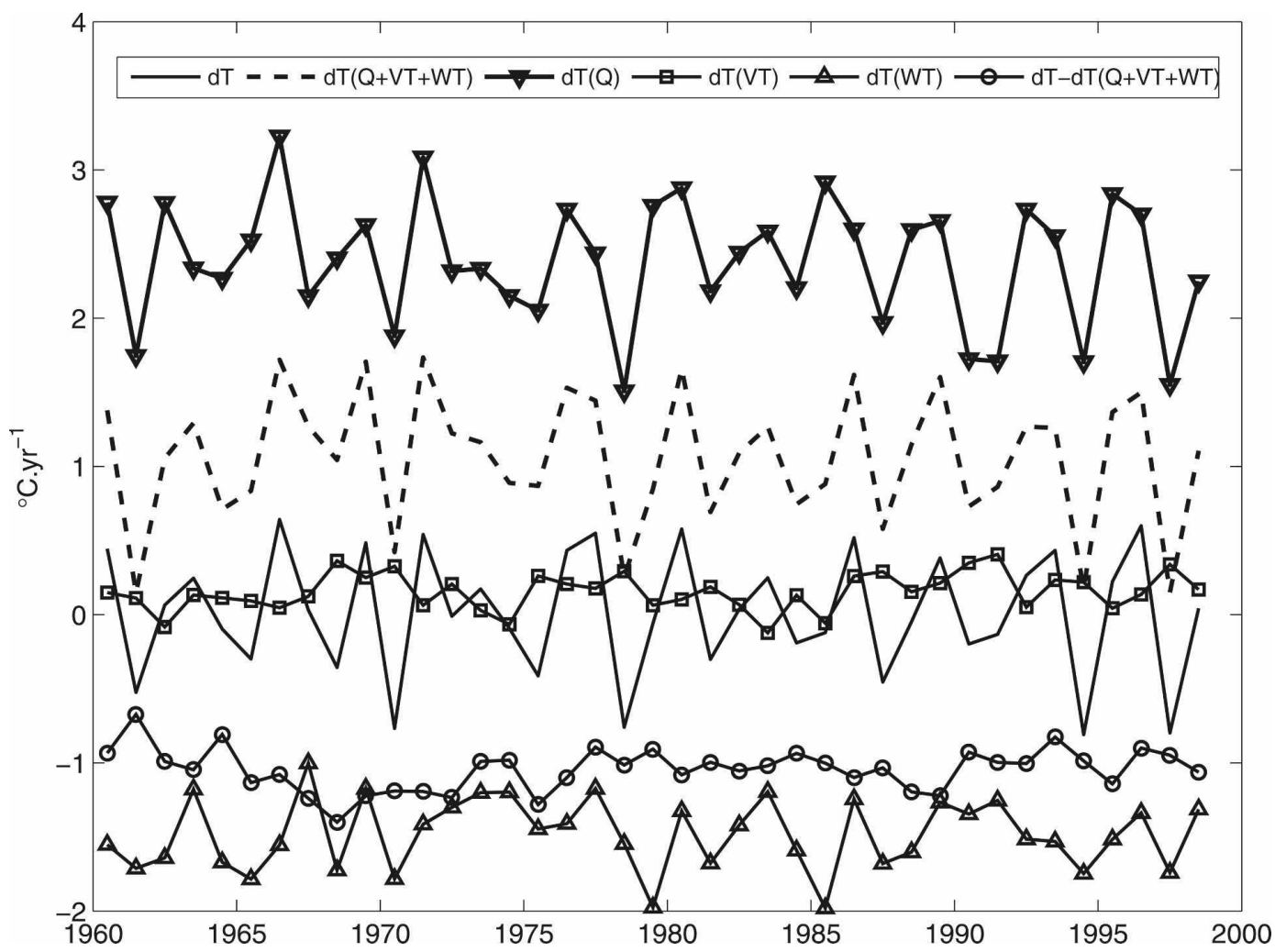

FIG. 8. Interannual variations of temperature simulated (solid black) and reconstituted from the heat budget (dashed black) defined as the sum of heat fluxes (downward triangles), meridional (squares), and vertical (upward triangles) advection heat terms, and the difference between the temperature simulated and reconstituted from this heat budget (circles) from CNRM-CM3 and for the 0-50-m layer of the equatorial Indian Ocean $\left(9^{\circ} \mathrm{S}-6^{\circ} \mathrm{N}\right)$.

periods. The mean atmospheric warming contribution has very significantly decreased by about $0.2^{\circ}{\mathrm{C} \mathrm{yr}^{-1}}^{-1}$ (Fig. 9c; $p=98 \%$ ). This shift in the long-term mean is obviously related to the decreasing trend of the net heat flux over 1960-99 (Fig. 5). A decomposition of the atmospheric heat term (Figs. 9e-h) shows that all flux components have significantly changed, and that the decrease in atmospheric warming is mostly due to an increase in the latent heat flux $\left(Q_{\text {lat }}\right)$ associated with evaporation (Fig. 9f), while a smaller decrease in the shortwave flux $\left(Q_{\text {sw }}\right)$ also contributes (Fig. 9e). The longwave $\left(Q_{\text {lw }}\right)$ and sensible $\left(Q_{\text {sens }}\right)$ heat fluxes have both decreased, acting as a damping term (Figs. 9g,h).

However, the decrease in the atmospheric warming is

TABLE 2. Mean value of the different heat budget terms computed from a 40-yr running window in the preindustrial control run and from the 1960-99 period in the twentieth-century run, changes in the 1960-99 period compared to the preindustrial control simulation, and their significance based on the PDFs shown in Fig. 9, assuming a symmetric distribution of the PDFs.

\begin{tabular}{|c|c|c|c|c|}
\hline Term & Preindustrial mean & 1960-99 period & Difference & Significance $(\%)$ \\
\hline Temperature trend $\left({ }^{\circ} \mathrm{C}\right)$ & -0.04 & 0.74 & +0.78 & 100 \\
\hline Temperature change $\left({ }^{\circ} \mathrm{C}\right)$ & -0.03 & 0.51 & +0.54 & 82.4 \\
\hline Atmospheric heat term $\left({ }^{\circ} \mathrm{C} \mathrm{yr}^{-1}\right)$ & 2.57 & 2.39 & -0.18 & 98.3 \\
\hline Shortwave heat flux $\left({ }^{\circ} \mathrm{C} \mathrm{yr}^{-1}\right)$ & 27.86 & 27.67 & -0.19 & 93.2 \\
\hline Latent heat flux $\left({ }^{\circ} \mathrm{C} \mathrm{yr}^{-1}\right)$ & -18.81 & -19.20 & -0.39 & 100 \\
\hline Longwave heat flux $\left({ }^{\circ} \mathrm{C} \mathrm{yr}^{-1}\right)$ & -5.08 & -4.79 & +0.29 & 100 \\
\hline Sensible heat flux $\left({ }^{\circ} \mathrm{C} \mathrm{yr}^{-1}\right)$ & -0.96 & -0.87 & +0.09 & 100 \\
\hline Oceanic heat term $\left({ }^{\circ} \mathrm{C}^{-1}\right)$ & -2.57 & -2.38 & +0.19 & 99.9 \\
\hline Advection $\left({ }^{\circ}{\left.\mathrm{C} \mathrm{yr}^{-1}\right)}^{\prime}\right.$ & -1.49 & -1.32 & +0.17 & 98.7 \\
\hline Meridional advection $\left({ }^{\circ} \mathrm{C} \mathrm{yr}^{-1}\right)$ & 0.09 & 0.16 & +0.07 & 69.5 \\
\hline Vertical advection $\left({ }^{\circ} \mathrm{C} \mathrm{yr}^{-1}\right)$ & -1.58 & -1.48 & +0.10 & 99.2 \\
\hline Diffusion $\left({ }^{\circ} \mathrm{C}^{-1}\right)$ & -1.09 & -1.05 & +0.04 & 71.2 \\
\hline
\end{tabular}


(a) $\mathrm{T}$ trend

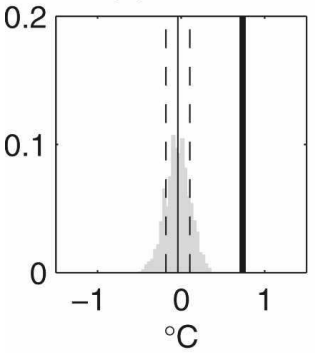

(e) Qsw

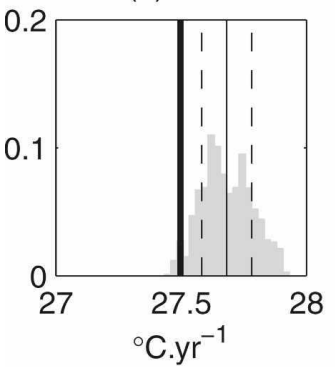

(i) Adv

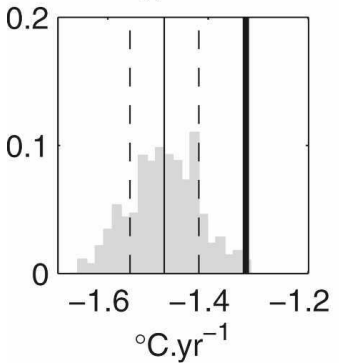

(b) dT

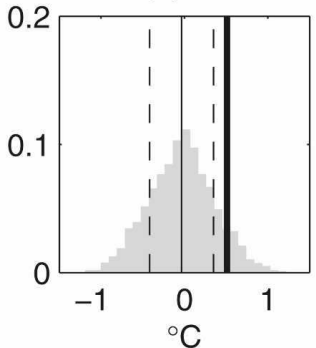

(f) Qlat

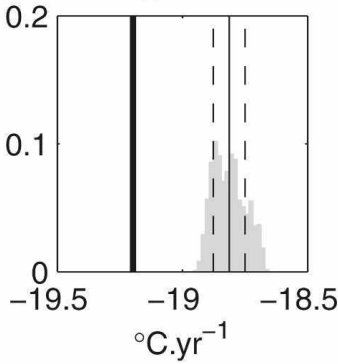

(j) V Adv

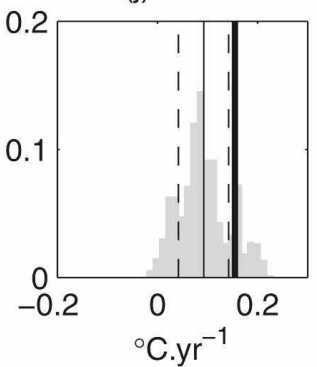

(c) dT Atm

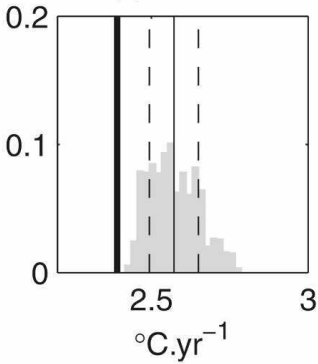

(g) Qlw

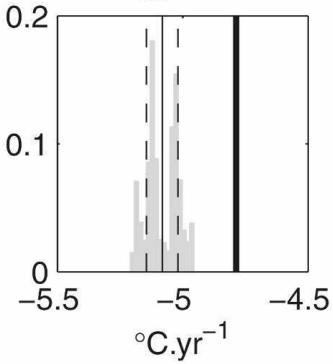

(k) W Adv

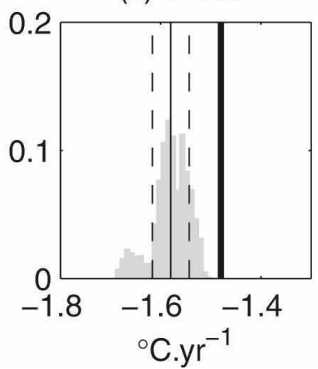

(d) dT Oc

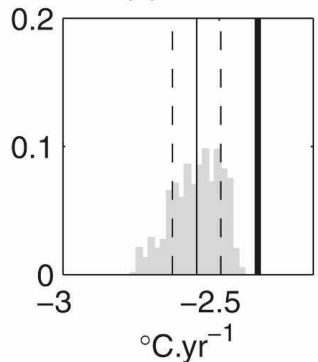

(h) Qsens

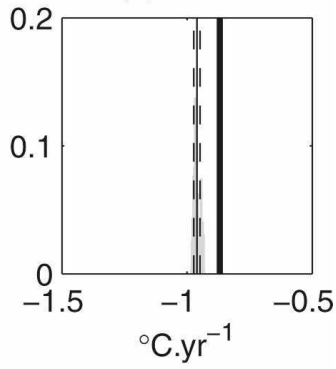

(I) Diff

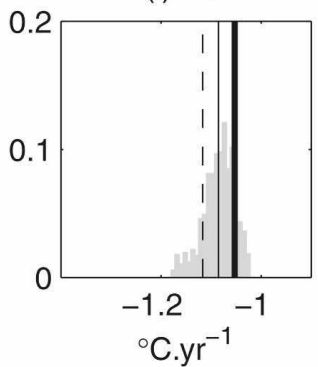

FIG. 9. (a) Long-term temperature trend; (b) temperature change; (c) atmospheric heat term; (d) oceanic heat term; atmospheric heat term decomposed into (e) shortwave, (f) latent, (g) longwave, and (h) sensible heat flux; oceanic heat term decomposed into (i) total advection, (j) meridional advection, (k) vertical advection, and (l) diffusion-eddy term simulated for the 1960-99 period (thick lines) and compared to the mean (thin line), std dev (dashed lines), and PDF (histogram) of the same terms simulated for the preindustrial period by the CNRM-CM3 model. All terms refer to the $0-50$-m layer of the equatorial Indian Ocean $\left(9^{\circ} \mathrm{S}-6^{\circ} \mathrm{N}\right)$. Mean values of the heat terms for the preindustrial and 1960-99 periods and percent of significance of the changes between these periods are reported in Table 2.

overcompensated by a slightly larger decrease in the mean oceanic cooling (Fig. 9d), which thus drives the SST warming. A decomposition of the oceanic heat term (Figs. 9i-1) reveals that the change in the oceanic contribution is mostly due to a very significant decrease ( $p=99 \%$ ) in the main cooling term: vertical advection (Fig. 9k). While meridional advection (Fig. 9j) and diffusion (Fig. 9l) also contribute to the warming, the changes in these heat terms are in the range of natural variability.

\section{d. Changes in vertical heat advection}

Following Eq. (C3) in appendix C, mean vertical heat advection at $50 \mathrm{~m}$ (Fig. 10e) is decomposed into two terms: the product of mean velocity and mean temperature (Fig. 10c) and a monthly eddy heat advection term
(Fig. 10d, submonthly eddy advection is part of the residual diffusion-eddy term). On spatial average in the equatorial band, both terms contribute about the same amount of cooling (Table 3). Mean velocity (Fig. 10a) and temperature (Fig. 10b) are both related to the mean wind field (Fig. 11a). In the south, the positive wind curl (Fig. 11b) drives upward velocity by Ekman pumping. This moves isotherms upward, with a cumulating effect in the west due to westward-propagating upwelling Rossby waves, creating a thermocline dome (Hermes and Reason 2008) that can be seen as a patch of negative temperature anomalies (relative to $T_{\text {box }}$ ) between $5^{\circ}$ and $10^{\circ} \mathrm{S}$ in Fig. 10b. Mean velocity and temperature combine here in a large patch of advective cooling (Fig. 10c). There is also a strong equatorial upwelling (Fig. 10a) off the African coast, likely associ- 
(a) $\bar{W}(\mathrm{~m} / \mathrm{s})$

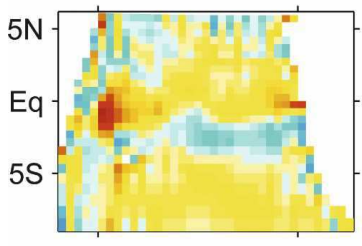

(d) $\overline{W^{\prime} \cdot T^{\prime}}\left({ }^{\circ} \mathrm{C} \cdot \mathrm{m} / \mathrm{s}\right)$

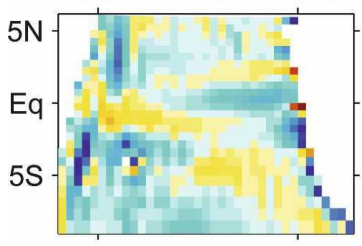

(g) $\Delta W(\mathrm{~m} / \mathrm{s})$

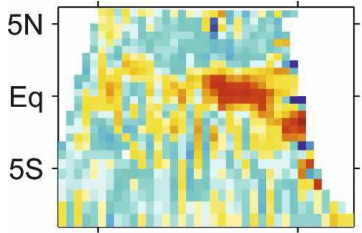

(j) $\bar{W} \cdot \Delta T\left({ }^{\circ} \mathrm{C} \cdot \mathrm{m} / \mathrm{s}\right)$

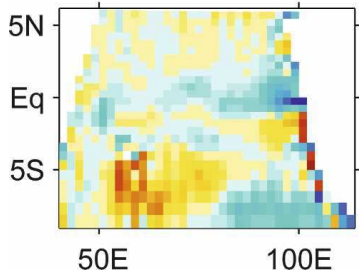

(b) $\bar{T}\left({ }^{\circ} \mathrm{C}\right)$

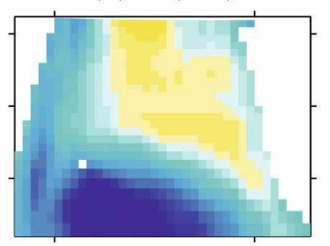

(e) $\overline{W . T}\left({ }^{\circ} \mathrm{C} . \mathrm{m} / \mathrm{s}\right)$

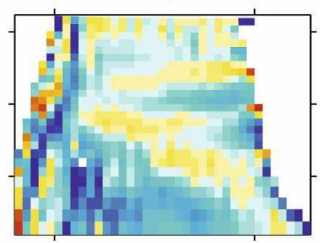

(h) $\Delta T\left({ }^{\circ} \mathrm{C}\right)$

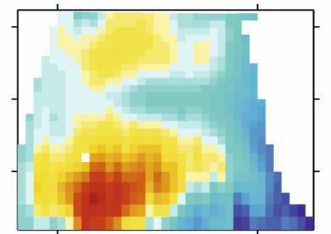

(k) $\Delta W \cdot \Delta T\left({ }^{\circ} \mathrm{C} . \mathrm{m} / \mathrm{s}\right)$

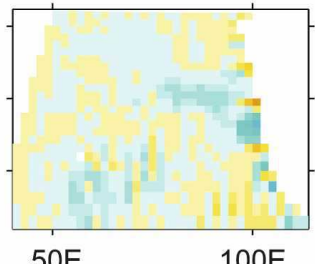

(c) $\bar{W} \cdot \bar{T}\left({ }^{\circ} \mathrm{C} \cdot \mathrm{m} / \mathrm{s}\right)$
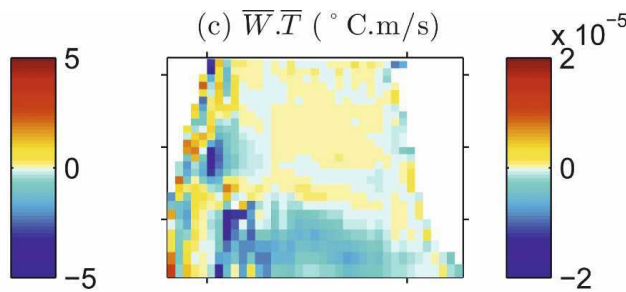

(f) $\Delta(W T)\left({ }^{\circ} \mathrm{C} . \mathrm{m} / \mathrm{s}\right)$
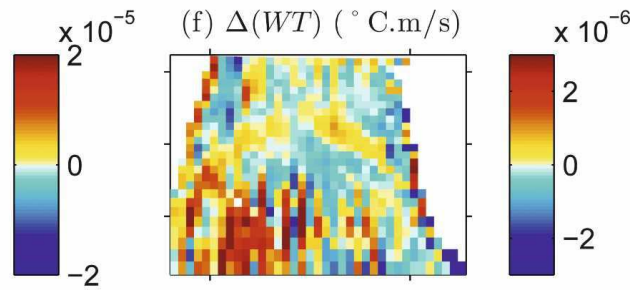

(i) $\Delta W \cdot \bar{T}\left({ }^{\circ} \mathrm{C} . \mathrm{m} / \mathrm{s}\right)$
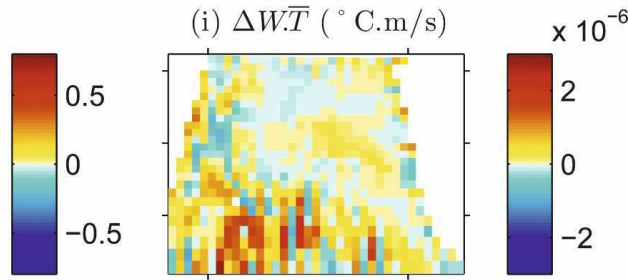

(l) $\Delta\left(W^{\prime} \cdot T^{\prime}\right)\left({ }^{\circ} \mathrm{C} \cdot \mathrm{m} / \mathrm{s}\right)$

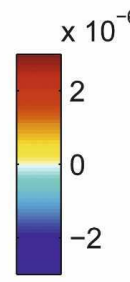

$50 \mathrm{E}$
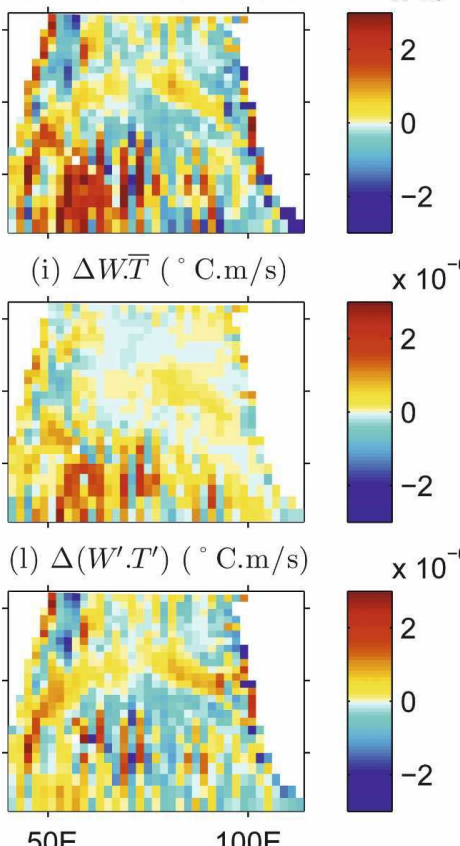

FIG. 10. Long-term mean in the CNRM-CM3 control simulation at 50-m depth of (a) vertical velocity $\bar{W}$, (b) temperature $\bar{T}$, and (c) vertical heat advection $\overline{W T}$ decomposed as the sum of (d) $\overline{W^{\prime} T^{\prime}}$ and (e) $\overline{W T}$. Changes (relative to the control period) in the $1960-99$ period of the CNRM-CM3 twentieth-century simulation of (g) vertical velocity $\Delta W$, (h) temperature $\Delta T$, and (f) vertical heat advection $\Delta(W T)$ decomposed as the sum of (i) $\Delta W \bar{T}$, (j) $\bar{W} \Delta T$, (k) $\Delta W \Delta T$, and (l) $\Delta\left(W^{\prime} T^{\prime}\right)$. Temperature is the temperature anomaly $T-T_{\text {box }}$. Velocity is positive when upward. Positive heat advection corresponds to a heat gain in the 0-50-m layer.

ated with the Southern Gyre (Schott and McCreary 2001). Cooling by eddy advection is maximum along the western boundary where coastal upwelling occurs seasonally because of alongshore winds (Fig. 10d).

Changes in vertical heat advection (Fig. 10f) are decomposed into four components (Figs. 10i-l; Table 3) following Eq. (C7). The $\Delta W \Delta T$ term (Fig. 10k) is small everywhere, while the $\Delta\left(W^{\prime} T^{\prime}\right)$ term (Fig. 10l) is locally strong but negligible on spatial average. The equatorial westward wind anomaly (Fig. 11c) drives an equatorial upwelling anomaly (Fig. 10g) that has little effect on heat advection (Fig. 10i). A decrease in wind curl in the south (Fig. 11d), particularly strong in the southeast where it can generate westward-propagating downwelling Rossby waves (Xie et al. 2002), affects both velocity and temperature at $50 \mathrm{~m}$. It produces a shift toward less advective cooling in the thermocline dome by both $\Delta W \bar{T}$ (Fig. 10i) and $\bar{W} \Delta T$ (Fig. 10j) processes. However, $\Delta W \bar{T}$ is stronger than $\bar{W} \Delta T$ in the thermocline dome; moreover $\bar{W} \Delta T$ is very small on spatial average (Table 3).

\section{e. Changes in meridional advection}

Changes in meridional advection are smaller than changes in vertical advection but also contribute to the

TABLE 3. Spatially averaged values of the vertical heat advection terms shown in Fig. 10.

\begin{tabular}{|c|c|c|c|c|c|c|c|c|c|c|c|c|c|}
\hline$\overline{W T}$ & $=$ & $\bar{W} \bar{T}$ & + & $\overline{\overline{W^{\prime} T^{\prime}}}$ & $\Delta(W T)$ & $=$ & $\bar{W} \Delta T$ & + & $\Delta W \bar{T}$ & + & $\Delta W \Delta T$ & + & $\Delta\left(W^{\prime} T^{\prime}\right)$ \\
\hline-1.57 & & -0.80 & & -0.77 & +0.0938 & & +0.0010 & & +0.1060 & & -0.0130 & & -0.0002 \\
\hline
\end{tabular}


(a) $\bar{\tau}(\mathrm{N} / \mathrm{m} 2)$

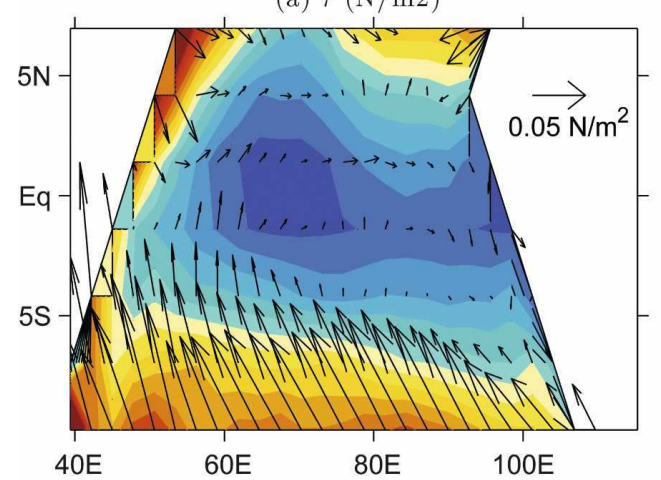

(c) $\Delta \tau(\mathrm{N} / \mathrm{m} 2)$

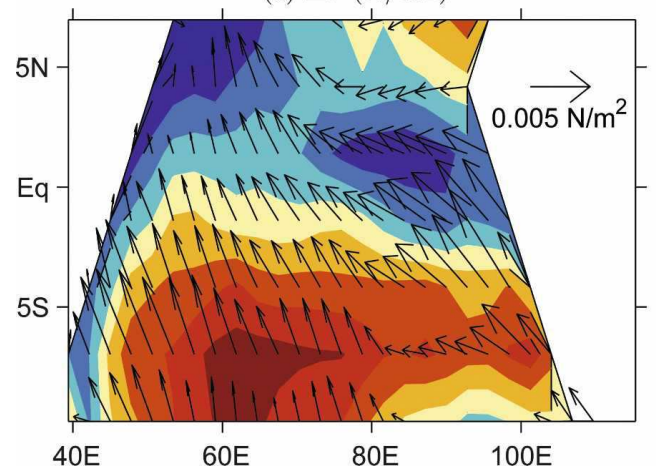

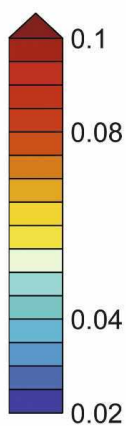

0.02

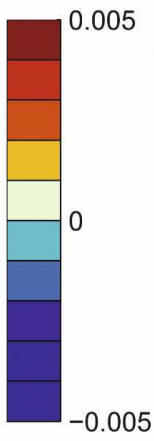

0.005

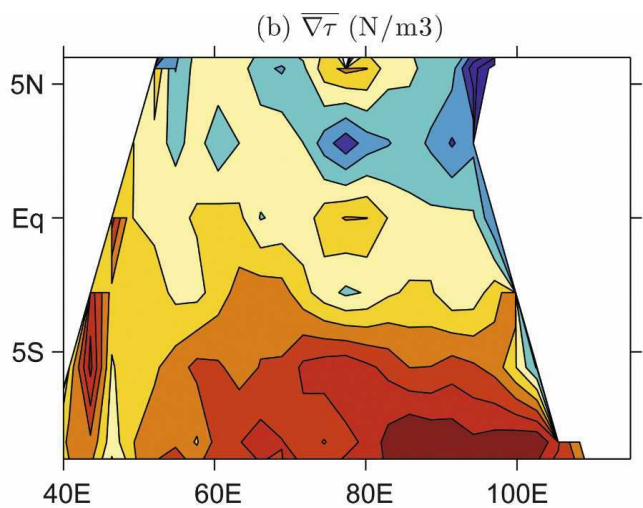

(d) $\Delta(\nabla \tau)(\mathrm{N} / \mathrm{m} 3)$

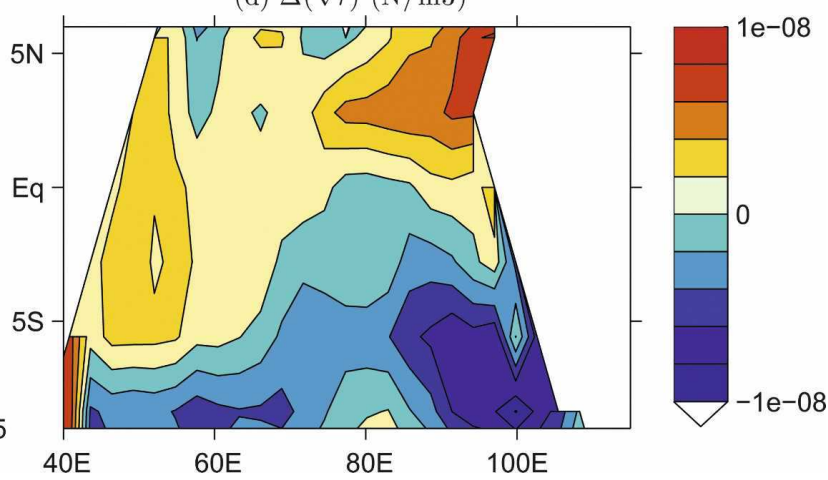

FIG. 11. Long-term mean in the CNRM-CM3 control simulation of (a) wind stress and (b) wind curl. Changes (relative to the control period) in the 1960-99 period of the CNRM-CM3 twentieth-century simulation of (c) wind stress and (d) wind curl.

equatorial warming (Table 2). However, they are not very significant, which means the climate change signal does not overcome natural variability. Nevertheless, we also decomposed the mean and changes in meridional advection following appendix $\mathrm{C}$ and across the different meridional boundaries of the box (Fig. 12). On average, eddy-advection terms are dominant and import heat from the south, which is partly compensated by a heat export to the Arabian Sea. The increase in meridional advective warming is equally due to heat gain from the Arabian Sea, Bay of Bengal, and from the south. Changes in eddy advection are dominant across the northern boundary. In the south, the increasing heat gain is mostly due to southward advection by the mean current of a negative $\Delta T$ (not shown). This apparent cooling at the southern boundary is in fact due to a (a)

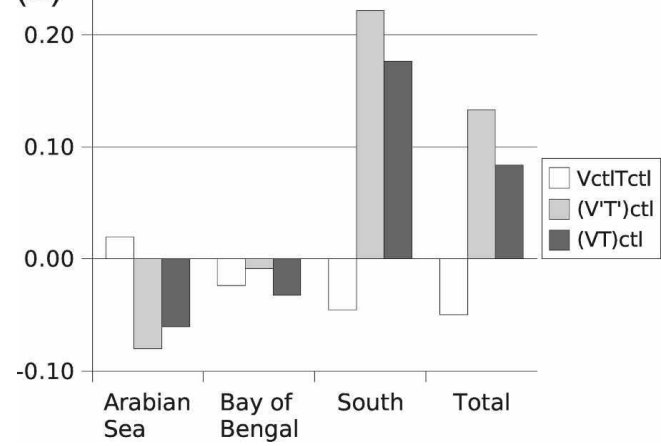

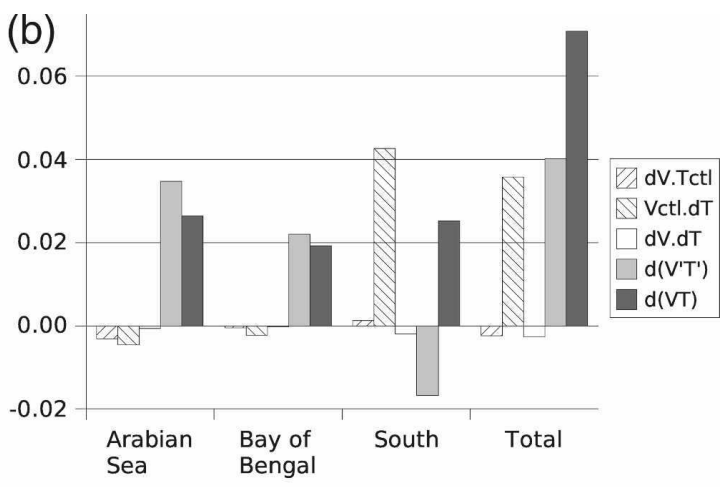

FIG. 12. Decomposition of the long-term (a) mean of meridional heat advection in the CNRM-CM3 control simulation and (b) changes of meridional heat advection in the 1960-99 period of the twentieth-century simulation relative to the control period. The decomposition is done for each meridional section of the heat budget box following Eqs. (C3) and (C7). Positive heat advection corresponds to a heat gain. 
(a) $\Delta$ Qnet $\left(\mathrm{W} \cdot \mathrm{m}^{-2}\right)$

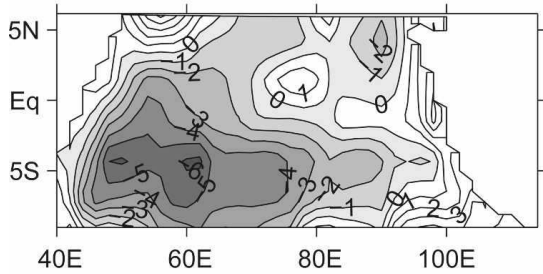

(c) $\Delta \mathrm{Qsw}\left(\mathrm{W} \cdot \mathrm{m}^{-2}\right)$

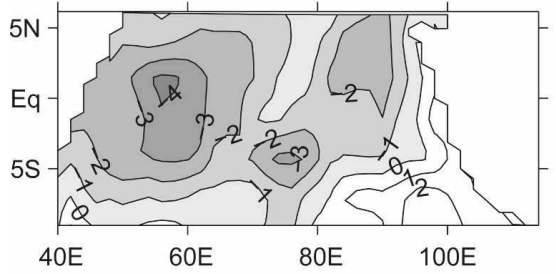

(e) $\Delta$ QIw $\left(\mathrm{W} \cdot \mathrm{m}^{-2}\right)$

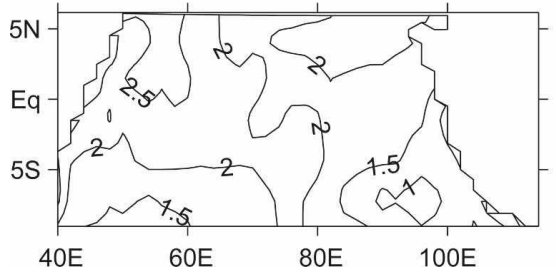

(b) $\Delta$ Cloud (\%)

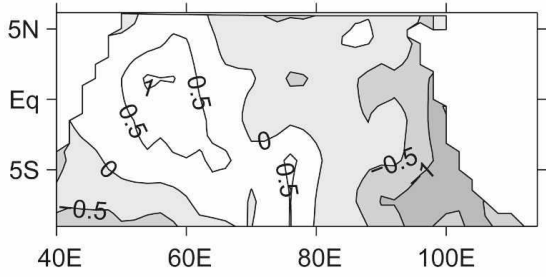

(d) $\Delta$ Qlat $\left(W \cdot m^{-2}\right)$

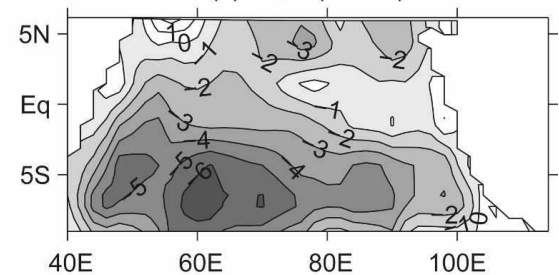

(f) $\Delta$ Qsens $\left(W \cdot m^{-2}\right)$

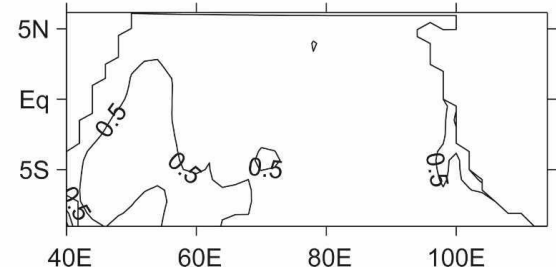

FIG. 13. Changes (relative to the control period) in the 1960-99 period of the CNRM-CM3 twentieth-century simulation of the net heat flux (a) $Q_{\text {net }}$, (b) cloud cover, (c) shortwave heat flux $Q_{\text {sw }}$, (d) latent heat flux $Q_{\text {lat }}$, (e) longwave heat flux $Q_{\text {lw }}$, and (f) sensible heat flux $Q_{\text {sens. }}$. Positive heat flux changes correspond to a downward increase.

lower warming rate compared to the box average, as we use relative temperature $\left(T-T_{\text {box }}\right)$ in Eq. (1).

\section{f. Changes in heat fluxes}

Changes in the different heat fluxes, as well as cloudiness, are shown in Fig. 13. It is clear that the decrease of the downward heat flux is mostly due to an increase in evaporation, as changes in $Q_{\text {lat }}$ (Fig. 13d) dominate the $Q_{\text {net }}$ changes pattern (Fig. 13a). This increase in evaporation is related to the strengthening of trade winds, as changes in $Q_{\text {lat }}$ (Fig. 13d) and wind speed (Fig. 11c) are strongly correlated. However, the wind effect is complemented by a general shift to enhanced evaporation due to the warming SST, following the ClaudiusClapeyron law (Knutson and Manabe 1995). Note that the strengthening of trade winds in the south (Fig. 11c) is a Gill atmosphere response to the meridional SST gradient in the warming pattern (Fig. 1).

Changes in $Q_{\text {lat }}$ also drive changes in the other fluxes. The large increase in evaporation in the southwest (Fig. 13d) means more moisture is available here for cloud formation. Indeed, downstream of this region following the mean trade winds (Fig. 11a), cloud cover is increased (Fig. 13b). The similarity of $Q_{\mathrm{sw}}$ and $Q_{\mathrm{lw}}$ changes (Figs. 13c,e) with cloud cover changes reflect a cloud filtering effect: cloud cover reduces the incoming $Q_{\text {sw }}$ and the heat loss by $Q_{\mathrm{lw}}$.

\section{Summary and discussion}

In the equatorial Indian Ocean, SST has warmed by $0.5^{\circ}-1^{\circ} \mathrm{C}$ over the $1960-99$ period, consistent with the ongoing climate change. Observations also show a subsurface cooling corresponding to a shoaling of the thermocline. A shoaling of the tropical thermocline has also been observed in the western Pacific, where the decreasing Walker circulation produces upwelling-favorable wind anomalies (Vecchi et al. 2006). In the Indian Ocean, the thermocline cooling could be due to a similar local process or/and transmitted from the western Pacific by the ITF (Han et al. 2006; Alory et al. 2007; Vecchi and Soden 2007; Wainwright et al. 2008).

While rising greenhouse gas concentration implies an increase in the global net heat flux, two different sets of atmospheric reanalysis suggest a regional decrease in the net heat flux in the equatorial Indian Ocean over the 1960-99 period, although with a very different amplitude. The scarcity of data available before the satellite era can bias long-term trends in atmospheric reanalyses (Alory et al. 2005) and explain differences also found in the wind trends. Similarly, an extensive com- 
parison of heat flux products on a more recent period (1988-2000), when the observation density is better and more datasets are available, reveals large differences between products, but all point to a stable or decreasing net heat flux in the tropical Indian Ocean ( $\mathrm{Yu}$ et al. 2007). The most consistent heat flux trend in the two reanalyses is an increase in the latent heat flux.

Among a set of 12 climate models including greenhouse forcing, the CNRM-CM3 model is one of the more realistic at reproducing the observed long-term trends described above, making it a suitable tool to investigate the changes in the heat budget responsible for the SST warming. The heat budget approach is commonly used to explain temperature variability at interannual and shorter time scales but has rarely been applied to explain long-term temperature trends. In the later case, a careful analysis (appendix B) shows that the long-term mean of heat budget terms, rather than their long-term trend, drives the long-term temperature trend. It implies that the trend in heat budget terms cannot directly explain the trend in SST, which has been assumed in previous studies (Liu and Huang 2000). It also implies that the long-term heat budget should be precisely closed. To fulfill this condition, nonlinear heat terms can be computed online at every time step of the model to explicitly close the heat budget (Liu et al. 2005). However, this is not applicable to WCRP CMIP3 simulations whose standard outputs are monthly averaged and do not include diffusion, which has to be estimated as a residual term.

In this study, we set a new methodology to investigate climate change-related shifts in the heat budget, when only monthly averaged model output is available. It consists of comparing, for a given time period, the long-term mean of the heat budget terms computed from a twentieth-century climate model simulation to its expected range of natural variability, extracted from a similar heat budget computed from the preindustrial control simulation. This method allows highlighting the heat budget terms that are significantly affected by changes in radiative forcing, in particular the anthropogenic greenhouse forcing. This is an efficient way to identify the physical processes responsible for longterm temperature trends.

When applied to the equatorial Indian Ocean, this method reveals that the SST warming, far outside the range of natural variability, is mostly due to oceanic processes, in particular vertical advection. Similarly, advection has been suggested to be the dominant process in the increase of the northern Indian Ocean heat content, contrary to other basins where heat fluxes prevail (Barnett et al. 2005). We find that the upwellingfavorable wind curl decreased in the south, which, through the $\Delta W \bar{T}$ term, decreased cooling in the thermocline dome region. This result is consistent with the slowdown of the southern meridional overturning cell over the recent period (Lee 2004), which in the long term is driven by the increasing sea level trend off Western Australia (Lee and McPhaden 2008). Therefore, while climate change is globally driven by thermodynamics, its regional expression in the equatorial Indian Ocean is mostly driven by ocean dynamics.

The decrease in oceanic cooling is only partially compensated by the decrease in atmospheric warming, though also significant. The net heat flux decrease is mostly due to an increase in evaporation, which also affects the other fluxes through cloudiness. The increase in evaporation is partly driven by a strengthening of the trade winds and by the surface warming, which enhances the hydrological cycle. Recent heat flux analyses suggest the trend in SST rather than wind speed is the main driver (Yu and Weller 2007). In fact, the strengthening of the trade winds is itself due to the SST warming pattern. Therefore the decrease in heat flux really is a negative feedback response to the SST warming, due to the strong ocean-atmosphere coupling in the equatorial Indian Ocean.

Acknowledgments. This work was funded by the Wealth from Oceans National Research Flagship and the Western Australian Marine Science Institution (WAMSI). NCEP data were provided by the NOAAESRL Physical Sciences Division, Boulder, Colorado, from their Web site at http://www.cdc.noaa.gov/. ERA40 data were obtained from the ECMWF data server. HadISST and ERSST data were obtained from the BADC data server. We acknowledge Susan Wijffels for preparing the IOTA dataset. We are grateful to David Salas y Melia for providing CNRM-CM3 outputs. Thanks to Stuart Godfrey, Takeshi Izumo, Fabien Durand, Ming Feng, and Gurvan Madec for fruitful discussions. Tong Lee and an anonymous reviewer provided constructive comments that greatly helped to improve the manuscript.

\section{APPENDIX A}

\section{Computation of the Interannual Heat Budget from Monthly Model Outputs}

To remove seasonal variability, we computed an interannual heat budget. Monthly heat terms were estimated from monthly means of heat flux, temperature, and currents available from the model. The monthly heat term, including atmospheric fluxes and oceanic advection $Q_{m}$, corresponds to the right-hand term in Eq. (1), neglecting the residual term. When $Q_{m}$ is inte- 


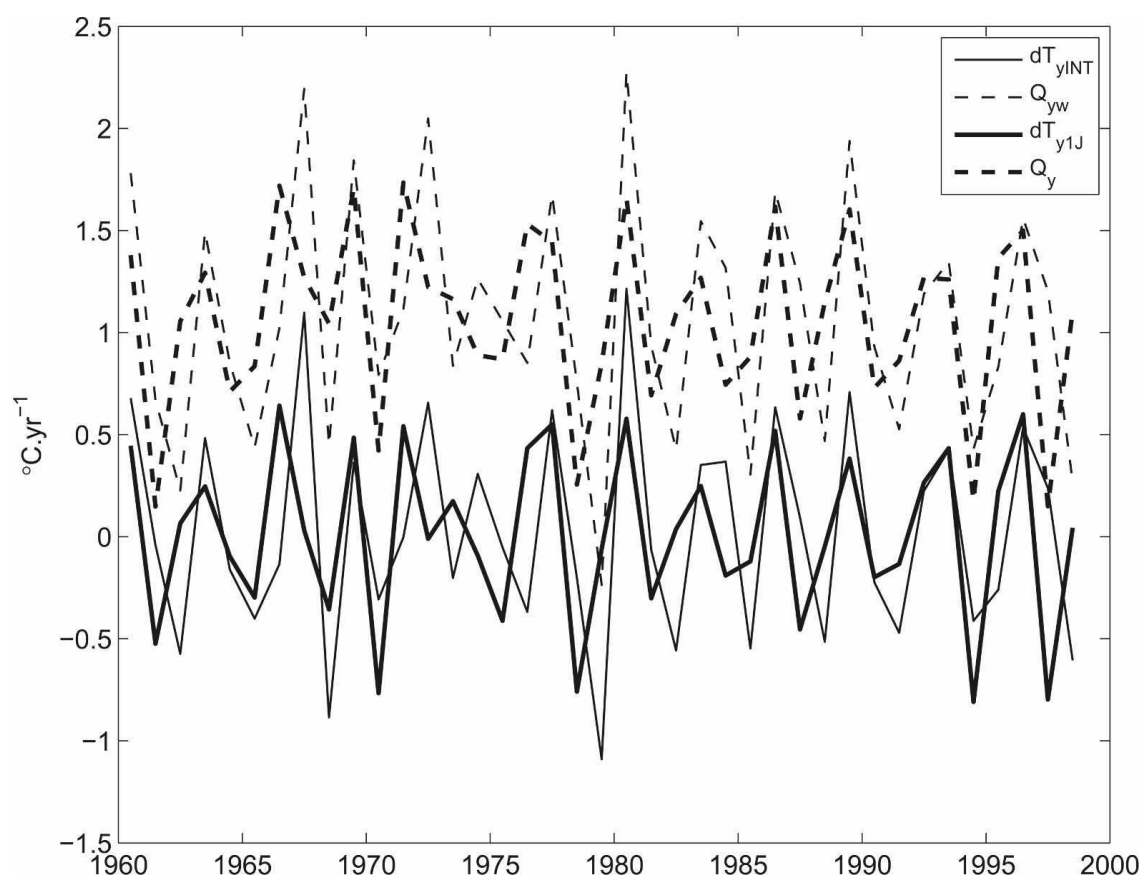

FIG. A1. Time series of temperature on 1 Jan (thin solid line), annual mean of temperature (thick solid line), annual mean of heat budget terms (thin dashed line), and weighted annual mean of heat budget terms (thick dashed line). All terms refer to the $0-50-\mathrm{m}$ layer of the equatorial Indian Ocean $\left(9^{\circ} \mathrm{S}-6^{\circ} \mathrm{N}\right)$ and are extracted from CNRM-CM3.

grated from 1 January to 31 December of a given year $y$, it contributes to $d T_{y 1 \mathrm{~J}}$, the temperature change from 1 January of year $y$ to 1 January of year $y+1$, which means that

$$
d T_{y 1 \mathrm{~J}}=\sum_{m=1}^{12} Q_{m}
$$

where $m$ represents the calendar month, and the righthand term is called $Q_{y}$. Instantaneous temperature on every 1 January were available from the model and used to compute $d T_{y 1 \mathrm{~J}}$. The $Q_{y}$ and $d T_{y 1 \mathrm{~J}}$ time series are shown in Fig. A1. They are slightly shifted because of the residual term but are indeed very well correlated $(r=0.97)$. This heat budget formulation can therefore explain annual temperature changes from a 1 January to the next. However, $d T_{y 1 \mathrm{~J}}$ does not properly represent interannual variability. While seasonal variability is removed because of the synchronized calendar day, $d T_{y 1 \mathrm{~J}}$ includes intraseasonal variability as it is based on instantaneous temperature.

Interannual temperature variability is more signifi- cantly represented by the difference between the annual means of temperature expressed as

$$
d T_{y \mathrm{INT}}=\frac{1}{12} \sum_{m=1}^{12} T_{m}^{y+1}-\frac{1}{12} \sum_{m=1}^{12} T_{m}^{y}
$$

where $T_{m}^{y}$ is the temperature averaged in month $m$ of year $y$. This can be rewritten as

$$
d T_{y \mathrm{INT}}=\frac{1}{12} \sum_{m=1}^{12}\left(T_{m}^{y+1}-T_{m}^{y}\right)
$$

Adapting Eq. (A1), we can write that

$$
\begin{aligned}
T_{m}^{y+1}-T_{m}^{y}= & \frac{1}{2} Q_{m}^{y}+\sum_{n=m+1}^{12} Q_{n}^{y}+\sum_{n=1}^{m-1} Q_{n}^{y+1} \\
& +\frac{1}{2} Q_{m}^{y+1}
\end{aligned}
$$

assuming that in month $m$ the average temperature is not too different from the instantaneous midmonth temperature, and the temperature change between the middle and the start/end of month is due to half the monthly averaged heat term. From (A3) and (A4) comes

$$
d T_{y \mathrm{INT}}=\frac{1}{12} \sum_{m=1}^{12}\left(\frac{1}{2} Q_{m}^{y}+\sum_{n=m+1}^{12} Q_{n}^{y}+\sum_{n=1}^{m-1} Q_{n}^{y+1}+\frac{1}{2} Q_{m}^{y+1}\right)
$$



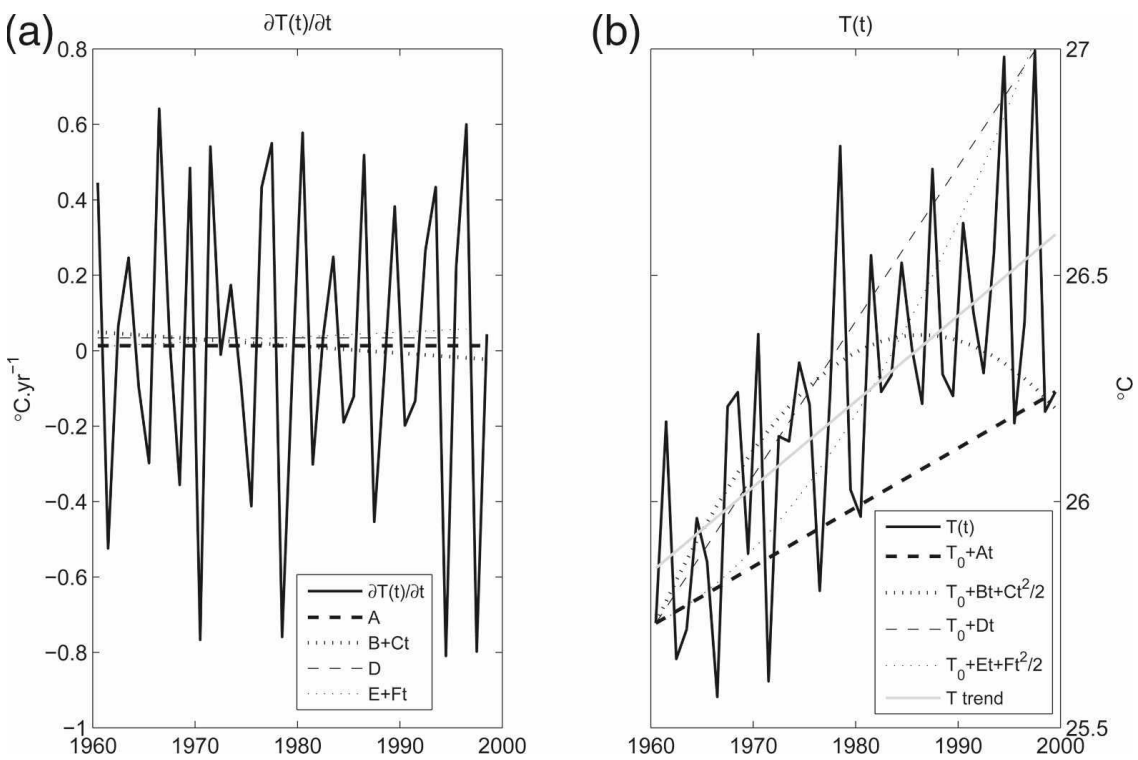

FIG. B1. (a) Annual rate of temperature change (thick solid line) with its 1960-99 long-term mean (thick dashed line), 1960-99 long-term trend (thick dotted line), 1960-97 long-term mean (thin dashed line), and 1960-97 long-term trend (thin dotted line). (b) Annual temperature (thick solid line) with its 1960-99 long-term trend (thick gray line) and temporal integration of the long-term means and trends shown in (a) with corresponding line styles. All terms refer to the $0-50-\mathrm{m}$ layer of the equatorial Indian Ocean $\left(9^{\circ} \mathrm{S}-6^{\circ} \mathrm{N}\right)$ and are extracted from CNRM-CM3.

which can be rewritten as

$d T_{y \mathrm{INT}}=\sum_{m=1}^{12} \frac{2 m-1}{24} Q_{m}^{y}+\sum_{m=1}^{12} \frac{25-2 m}{24} Q_{m}^{y+1}$

where the right-hand term, called $Q_{y w}$, is a weighted integral of the monthly heat terms of years $y$ and $y+1$. The $Q_{y w}$ and $d T_{y \mathrm{INT}}$ time series are shown in Fig. A1. Again, they are slightly shifted because of the residual term but are very well correlated $(r=0.95)$. On the opposite, $d T_{y 1 \mathrm{~J}}$ and $d T_{y \mathrm{INT}}$ are only moderately correlated $(r=0.43)$ because of the intraseasonal variability included in $d T_{y 1 \mathrm{~J}}$. In this paper and particularly in Fig. 8, we use the formulation presented in Eq. (A6) rather than (A1), as the former is more suitable to study interannual variability and longer time scales.

\section{APPENDIX B}

\section{Interpretation of Long-Term Trend and Mean of Heat Budget Terms for the Long-Term Temperature Trend}

While the heat budget is a tool widely used to understand intraseasonal to interannual temperature variations, it has rarely been applied to understand longterm temperature trends. However, this approach is likely to develop in the climate change context, where it can rely on the increasingly realistic climate simulations available. The interpretation of the heat budget at this time scale, and particularly of the long-term trend and mean of its different terms, requires caution as explained here.

Figure B1 shows the annual temperature change $(\partial T / \partial t)$ and annual temperature time series in the equatorial Indian Ocean from the CNRM-CM3 model. The former is given by the heat budget Eq. (1) and extracted from Fig. 8; the latter includes the warming trend we wish to explain and is extracted from Fig. 2. The former is simply time derived from the latter. The long-term mean and trend of $\partial T / \partial t$ (shown as lines in Fig. B1 for the 1960-99 and 1960-97 periods) result from the contribution of the different heat terms [right-hand terms in Eq. (1)]. The mean is slightly positive and the trend slightly negative for the 1960-99 period. A simple time integration shows that the long-term mean of $\partial T / \partial t$ corresponds to the temperature change over the whole period, while its long-term trend is secondary and corresponds to a quadratic fit of the temperature time series (Fig. B1). Consequently, a negative long-term trend in $\partial T / \partial t$ is not inconsistent with a long-term SST warming, as illustrated with the 1960-99 period. The $\partial T / \partial t$ trend is also very sensitive to interannual variability as, in the present study, it becomes positive when considering the 1960-97 period instead of 1960-99. On 
the contrary, the $\partial T / \partial t$ mean is consistently positive when considering a period long enough that the longterm SST warming outruns interannual variability. However, because of interannual variability, the longterm warming is underestimated by the temperature change in the 1960-99 period and overestimated when considering the 1960-97 period (Fig. B1).

This analysis reveals that the long-term mean of heat budget terms, rather than their long-term trend, drive the long-term temperature trend. It implies that a mean reference state is needed to study changes in the longterm mean of heat budget terms. In the context of anthropogenic climate change studies based on models, these changes can be estimated by comparing a twentieth-century simulation including radiative forcing to the corresponding preindustrial control simulation, as done in the present study.

\section{APPENDIX C}

\section{Decomposition of Heat Advection}

At every grid point, the time mean of a heat advection term on a given period can be written as

$$
\overline{V T}=\overline{\left(\bar{V}+V^{\prime}\right)\left(\bar{T}+T^{\prime}\right)},
$$

where $\bar{X}$ and $X^{\prime}$ denote the mean and eddy term of variable $X$, respectively. As $\overline{X^{\prime}}=0$ and $\overline{\bar{X}}=\bar{X}$, it further comes that

$$
\overline{V T}=\overline{\bar{V}} \bar{T}+\bar{V} T^{\prime}+V^{\prime} \bar{T}+V^{\prime} T^{\prime}
$$

can be simplified in

$$
\overline{V T}=\bar{V} \bar{T}+\overline{V^{\prime} T^{\prime}} .
$$

Now, the change in heat advection between the preindustrial and the twentieth-century period can be written as

$$
\Delta(V T)=\overline{V T}^{20 C}-\overline{V T}^{\mathrm{CTL}},
$$

or, using (C3),

$$
\Delta(V T)=\bar{V}^{20 C} \bar{T}^{20 C}-\bar{V}^{\mathrm{CTL}} \bar{T}^{\mathrm{CTL}}+\Delta\left(V^{\prime} T^{\prime}\right) .
$$

Taking the preindustrial period as a reference, this further gives

$$
\Delta(V T)=(\bar{V}+\Delta V)(\bar{T}+\Delta T)-\bar{V} \bar{T}+\Delta\left(V^{\prime} T^{\prime}\right),
$$

which eventually gives

$$
\Delta(V T)=\bar{V} \Delta T+\Delta V \bar{T}+\Delta V \Delta T+\Delta\left(V^{\prime} T^{\prime}\right),
$$

where the sum represents the changes in heat advection due to, respectively, the change in temperature, the change in velocity, the covariant changes in velocity and temperature, and the change in eddy advection.

\section{REFERENCES}

Alory, G., S. Cravatte, T. Izumo, and K. B. Rodgers, 2005: Validation of a decadal OGCM simulation for the tropical Pacific. Ocean Modell., 10, 272-282, doi:10.1016/j.ocemod.2004.08. 003.

- S. Wijffels, and G. Meyers, 2007: Observed temperature trends in the Indian Ocean over 1960-1999 and associated mechanisms. Geophys. Res. Lett., 34, L02606, doi:10.1029/ 2006 GL028044.

Ashok, K., Z. Guan, and T. Yamagata, 2003: Influence of the Indian Ocean Dipole on the Australian winter rainfall. Geophys. Res. Lett., 30, 1821, doi:10.1029/2003GL017926.

Barnett, T. P., D. W. Pierce, K. M. Achutarao, P. J. Gleckler, B. D. Santer, J. M. Gregory, and W. M. Washington, 2005: Penetration of human-induced warming into the world's oceans. Science, 309, 284-287.

Cai, W., and P. H. Whetton, 2001: A time-varying greenhouse warming pattern and the tropical-extratropical circulation linkage in the Pacific Ocean. J. Climate, 14, 3337-3355.

Clarke, J., and A. Lebedev, 1996: Long-term changes in the equatorial Pacific trade winds. J. Climate, 9, 1020-1029.

Delworth, T. L., and Coauthors, 2006: GFDL's CM2 global coupled climate models. Part I: Formulation and simulation characteristics. J. Climate, 19, 643-674, doi:10.1175/JCLI3629.1.

Findlater, J., 1969: A major low-level air current near the Indian Ocean during the northern summer. Quart. J. Roy. Meteor. Soc., 95, 362-380.

Flato, G. M., G. J. Boer, W. G. Lee, N. A. McFarlane, D. Ramsden, M. C. Reader, and A. J. Weaver, 2000: The Canadian Centre for Climate Modelling and Analysis global coupled model and its climate. Climate Dyn., 16, 451-467.

Furevik, T., M. Bentsen, H. Drange, I. K. T. Kindem, N. G. Kvamsto, and A. Sorteberg, 2003: Description and evaluation of the Bergen climate model: ARPEGE coupled with MICOM. Climate Dyn., 21, 27-51.

Giannini, A., R. Saravanan, and P. Chang, 2003: Oceanic forcing of Sahel rainfall on interannual to interdecadal time scales. Science, 302, 1027-1030.

Gordon, A. L., 2005: Oceanography of the Indonesian Seas and their throughflow. Oceanography, 18, 14-27.

Gordon, C., C. Cooper, C. Senior, H. Banks, J. Gregory, T. Johns, J. Mitchell, and R. Wood, 2000: The simulation of SST, sea ice extents and ocean heat transports in the Hadley Centre coupled model without flux adjustments. Climate Dyn., 16, 147-168.

Gordon, H. B., and Coauthors, 2002: The CSIRO Mk3 climate system model, Tech. Rep. 60, CSIRO Marine and Atmospheric Research, Aspendale, Victoria, Australia, 134 pp.

Gronell, A., and S. E. Wijffels, 2008: A semiautomated approach for quality controlling large historical ocean temperature archives. J. Atmos. Oceanic Technol., 25, 990-1003.

Han, W., G. A. Meehl, and A. Hu, 2006: Interpretation of tropical thermocline cooling in the Indian and Pacific oceans during recent decades. Geophys. Res. Lett., 33, L23615, doi:10.1029/ 2006 GL027982.

Harrison, D. E., and M. Carson, 2007: Is the world ocean warming? Upper ocean trends, 1950-2000. J. Phys. Oceanogr., 37, 174-187.

Hasumi, M., and S. Emori, 2004: K-1 coupled GCM (MIROC) 
description. Tech. Rep., Center for Climate System Research, University of Tokyo, Tokyo, Japan, 34 pp.

Hermes, J. C., and C. J. C. Reason, 2008: Annual cycle of the South Indian Ocean (Seychelles-Chagos) thermocline ridge in a regional ocean model. J. Geophys. Res., 113, C04035, doi:10.1029/2007JC004363.

Hoerling, M., and A. Kumar, 2003: The perfect ocean for drought. Science, 299, 691-694.

_ J. W. Hurrell, T. Xu, G. T. Bates, and A. S. Phillips, 2004: Twentieth century North Atlantic climate change. Part II: Understanding the effect of Indian Ocean warming. Climate Dyn., 23, 391-405.

,-- J. Eischeid, and A. Phillips, 2006: Detection and attribution of twentieth-century northern and southern African rainfall change. J. Climate, 19, 3989-4008.

Hu, R., Q. Liu, Q. Wang, J. S. Godfrey, and X. Meng, 2005: The shallow meridional overturning circulation in the Northern Indian Ocean and its interannual variability. Adv. Atmos. Sci., 22, 220-229.

Kistler, R., and Coauthors, 2001: The NCEP-NCAR 50-Year Reanalysis: Monthly means CD-ROM and documentation. Bull. Amer. Meteor. Soc., 82, 247-268.

Knutson, T. R., and S. Manabe, 1995: Time-mean response over the tropical Pacific due to increased $\mathrm{CO}_{2}$ in a coupled oceanatmosphere model. J. Climate, 8, 2181-2199.

— , T. L. Delworth, K. W. Dixon, I. M. Held, J. Lu, V. Ramaswamy, and M. D. Schwarzkopf, 2006: Assessment of twentieth-century regional surface temperature trends using the GFDL CM2 coupled models. J. Climate, 19, 1624-1651.

Krishnan, R., K. V. Ramesh, B. K. Samala, G. Meyers, J. M. Slingo, and M. J. Fennessy, 2006: Indian Ocean-monsoon coupled interactions and impending monsoon droughts. Geophys. Res. Lett., 33, L08711, doi:10.1029/2006GL025811.

Lee, T., 2004: Decadal weakening of the shallow overturning circulation in the South Indian Ocean. Geophys. Res. Lett., 31, L18305, doi:10.1029/2004GL020884.

— turning and heat transport of the Indian Ocean. J. Phys. Oceanogr., 28, 923-943.

—, and M. McPhaden, 2008: Decadal phase change in largescale sea level and winds in the Indo-Pacific region at the end of the 20th century. Geophys. Res. Lett., 35, L01605, doi:10.1029/2007GL032419.

_ I. Fukumori, and B. Tang, 2004: Temperature advection: Internal versus external processes. J. Phys. Oceanogr., 34, 1936-1944.

Levitus, S., J. I. Antonov, J. Wang, T. L. Delworth, K. W. Dixon, and A. J. Broccoli, 2001: Anthropogenic warming of Earth's climate system. Science, 292, 267-270.

- - - and T. Boyer, 2005: Warming of the world ocean, 1955-2003. Geophys. Res. Lett., 32, L02604, doi:10.1029/ 2004GL021592.

Liu, Z., and B. Huang, 2000: Cause of tropical Pacific warming trend. Geophys. Res. Lett., 27, 1935-1938.

— S. Vavrus, F. He, N. Wen, and Y. Zhong, 2005: Rethinking tropical ocean response to global warming: The enhanced equatorial warming. J. Climate, 18, 4684-4700.

Lu, J., R. J. Greatbatch, and K. A. Peterson, 2004: Trend in Northern Hemisphere winter atmospheric circulation during the last half of the twentieth century. J. Climate, 17, 37453760 .

Madec, G., P. Delecluse, M. Imbard, and C. Levy, 1998: OPA 8.1
Ocean General Circulation Model reference manual. Notes du pôle de modélisation de l'IPSL 11, 91 pp.

Marti, O., and Coauthors, 2005: The new IPSL climate system model: IPSL-CM4. Tech. Rep., IPSL, Paris, France, 86 pp. [Available online at http://dods.ipsl.jussieu.fr/omamce/ IPSLCM4/DocIPSLCM4/FILES/DocIPSLCM4.pdf.]

Miyama, T., J. P. McCreary Jr., T. G. Jensen, J. Loschnigg, S. Godfrey, and A. Ishida, 2003: Structure and dynamics of the Indian Ocean cross-equatorial cell. Deep-Sea Res. II, 50, 2023-2047.

Rayner, N. A., E. B. Horton, D. E. Parker, C. K. Folland, and R. B. Hackett, 1996: Version 2.2 of the global sea-ice and sea surface temperature data set, 1903-1994. Climate Research Tech. Note 74, 43 pp. [Available online at http://hadobs. metoffice.com/gisst/crtn74.pdf.]

, D. E. Parker, E. B. Horton, C. K. Folland, L. V. Alexander, D. P. Rowell, E. C. Kent, and A. Kaplan, 2003: Global analyses of sea surface temperature, sea ice, and night marine air temperature since the late nineteenth century. J. Geophys. Res., 108, 4407, doi:10.1029/2002JD002670.

Reynolds, R. W., N. A. Rayner, T. M. Smith, D. C. Stokes, and W. Wang, 2002: An improved in situ and satellite SST analysis for climate. J. Climate, 15, 1609-1625.

Ridderinkhof, H., and W. P. M. de Ruijter, 2003: Moored current observations in the Mozambique Channel. Deep-Sea Res. II, 50, 1933-1955.

Ridgway, K. R., J. R. Dunn, and J. L. Wilkin, 2002: Ocean interpolation by four-dimensional weighted least squaresApplication to the waters around Australasia. J. Atmos. Oceanic Technol., 19, 1357-1375.

Saji, N. H., B. N. Goswani, P. N. Vinayachandran, and T. Yamagata, 1999: A dipole mode in the tropical Indian Ocean. $\mathrm{Na}$ ture, 401, 360-363, doi:10.1038/43855.

- S.-P. Xie, and T. Yamagata, 2006: Tropical Indian Ocean variability in the IPCC twentieth-century climate simulations. J. Climate, 19, 4397-4417.

Salas-Melia, D., and Coauthors, 2005: Description and validation of the CNRM-CM3 global coupled model. CNRM Tech. Rep. 103, 36 pp.

Schoenefeldt, R., and F. A. Schott, 2006: Decadal variability of the Indian Ocean cross-equatorial exchange in SODA. Geophys. Res. Lett., 33, L08602, doi:10.1029/2006GL025891.

Schott, F., and J. P. McCreary, 2001: The monsoon circulation of the Indian Ocean. Prog. Oceanogr., 51, 1-123.

_, M. Dengler, and R. Schoenefeldt, 2002: The shallow thermohaline circulation of the Indian Ocean. Prog. Oceanogr., 53, 57-103.

Smith, T. M., and R. W. Reynolds, 2004: Improved extended reconstruction of SST (1854-1997). J. Climate, 17, 2466-2477.

Uppala, S. M., and Coauthors, 2005: The ERA-40 Re-Analysis. Quart. J. Roy. Meteor. Soc., 131, 2961-3012, doi:10.1256/ qj.04.176.

Vecchi, G. A., and B. J. Soden, 2007: Global warming and the weakening of the tropical circulation. J. Climate, 20, 43164340.

- A. T. Wittenberg, I. M. Held, A. Leetmaa, and M. J. Harrison, 2006: Weakening of tropical Pacific atmospheric circulation due to anthropogenic forcing. Nature, 441, 73-76.

Wainwright, L., G. Meyers, S. Wijffels, and L. Pigot, 2008: Change in the Indonesian Throughflow with the climatic shift of 1976/ 77. Geophys. Res. Lett., 35, L03604, doi:10.1029/2007GL031911.

Xie, S.-P., H. Annamalai, F. Schott, and J. P. McCreary Jr., 2002: 
Structure and mechanisms of South Indian Ocean climate variability. J. Climate, 15, 864-874.

Yu, L., and R. A. Weller, 2007: Objectively analyzed air-sea heat fluxes for the global ice-free oceans (1981-2005). Bull. Amer. Meteor. Soc., 88, 527-539.

_, X. Jin, and R. A. Weller, 2007: Annual, seasonal, and interannual variability of air-sea heat fluxes in the Indian Ocean. J. Climate, 20, 3190-3209.
Yu, Y., X. Zhang, and Y. Guo, 2004: Global coupled oceanatmosphere general circulation models in LASGP/IAS. $A d v$. Atmos. Sci., 21, 444-455.

Yukimoto, S., and A. Noda, 2002: Improvements of the Meteorological Research Institute Global Ocean-Atmosphere Coupled GCM (MRICGCM2) and its climate sensitivity. Tech. Rep. 10, National Institute for Environmental Studies, Tsukuba, Japan, 8 pp. 